\title{
Development of an Ingestion Pathway Model for AXALRQ(U)
}

D. R. Marx DRM

A. A. Simpkins $/ / 2$
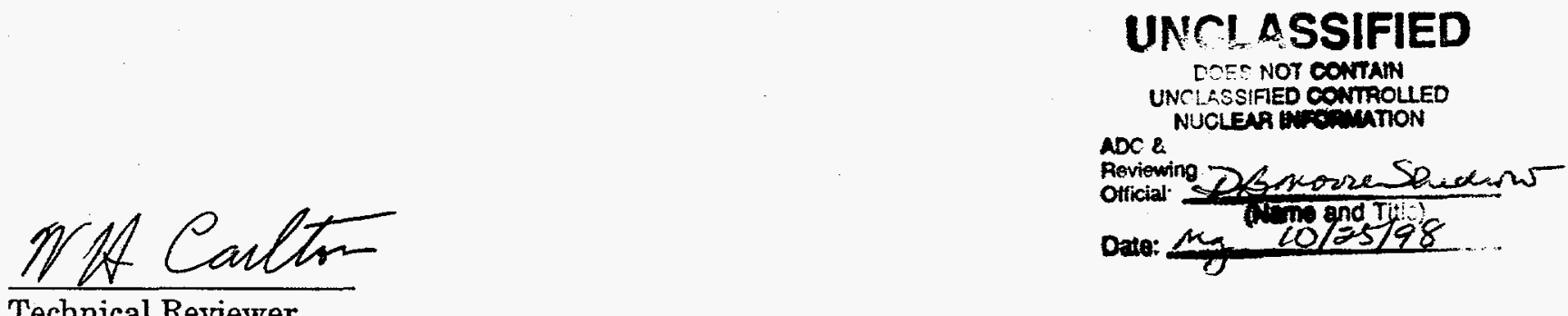

June 1998

Westinghouse Savannah River Company Savannah River Site Aiken, SC 29808

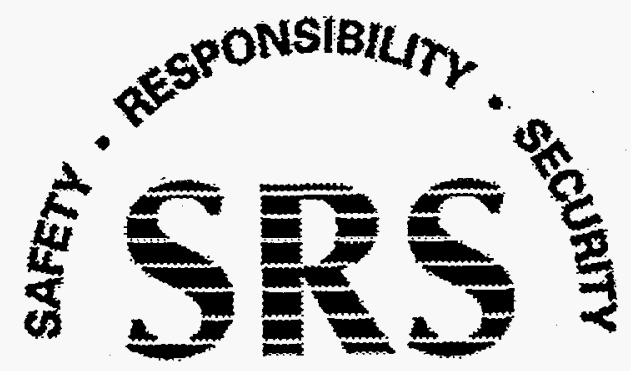




\section{DISCLAIMER}

This report was prepared as an account of work sponsored by an agency of the United States Government. Neither the United States Government nor any agency thereof, nor any of their employees, makes any warranty, express or implied, or assumes any legal liability or responsibility for the accuracy, completeness, or usefulness of any information, apparatus, product, or process disclosed, or represents that its use would not infringe privately owned rights. Reference herein to any specific commercial product, process, or service by trade name, trademark, manufacturer, or otherwise does not necessarily constitute or imply its endorsement, recommendation, or favoring by the United States Government or any agency thereof. The views and opinions of authors expressed herein do not necessarily state or reflect those of the United States Government or any agency thereof.

This report has been reproduced directly from the best available copy.

Available to DOE and DOE contractors from the Office of Scientific and Technical Information, P.O. Box 62, Oak Ridge, TN 37831; prices available from (615) 576-8401.

Available to the public from the National Technical Information Service, U.S. Department of Commerce, 5285 Port Royal Road, Springfield, VA 22161. 


\section{DISCLAIMER}

Portions of this document may be illegible in electronic image products. Images are produced from the best available original document. 


\author{
Key Words Ingestion Model \\ Atmospheric Dispersion \\ Dose Determination \\ Atmospheric Release
}

Retention: Lifetime

\title{
Development of an Ingestion Pathway Model for AXAIRQ(U)
}

\author{
D. R. Marx \\ A. A. Simpkins
}

Issued: June 1998 


\section{ABSTRACT ${ }^{*}$}

AXAIRQ is a dose model code used for prospective accident assessment at the Savannah River Site and is primarily used to show regulatory compliance. For completeness of pathway analysis, an ingestion model, AXINGST, has been developed for use with, and incorporation in, AXAIRQ. Currently available ingestion models were referenced as a basis for AXINGST. AXINGST calculates a conservative ingestion dose following an atmospheric release of radionuclides and includes site specific variables where applicable.

\footnotetext{
* The research was performed under appointment to the Applied Health Physics Fellowship Program administered by Oak Ridge Institute for Science and Education under contract number DE-AC05760R00033 between the U.S. Department of Energy and Oak Ridge Associated Universities.
} 


\section{TABLE OF CONTENTS}

1.0 Introduction

2.0 Objective

3.0 Background

3.1 AXAIRQ

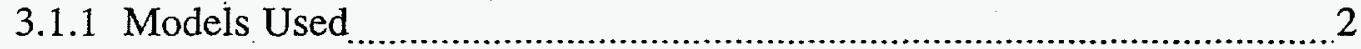

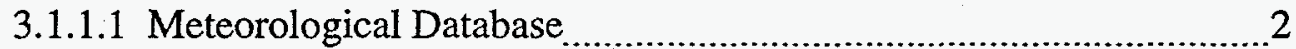

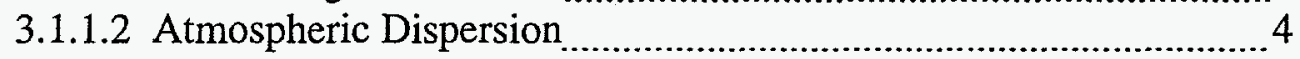

3.1.1.3 Deposition Velocity ................................................................... 4

3.1.1.4 Current Pathways ................................................................... 5

3.1.2 Determination of Reported Dose

3.2 Ingestion Models Available

3.2.1 PATHWAY $\ldots \ldots \ldots-1-1$

3.2.2 COMIDA

3.2.3 ECOSYS-87

4.0 Approach/Method

5.0 Results

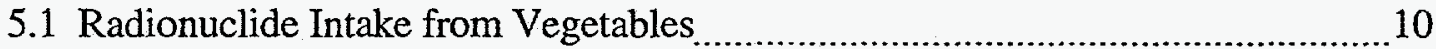

5.1.1 Initial Crop Contamination

5.1.2 Concentration in Following Years Crop

5.1.3 Calculation of Intake

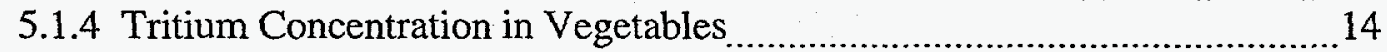

5.2 Radionuclide Intake from Meat

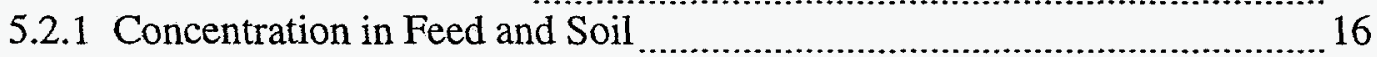

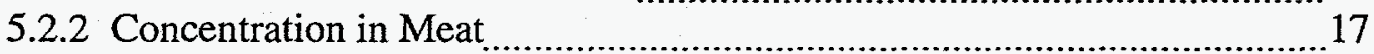

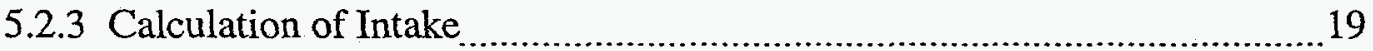

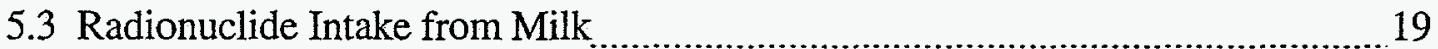

5.4 Determination of Daughter Ingrowth

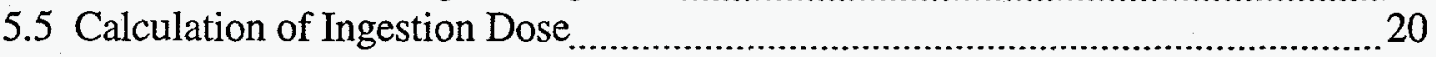

6.0 Discussion

7.0 Conclusion

8.0 References

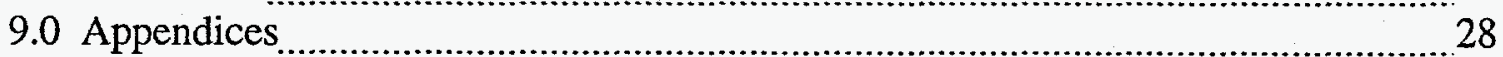

9.1 List of Equations and Variables

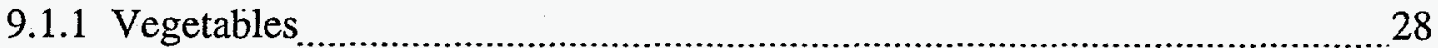

9.1.2 Meat and Milk

9.2 Hand Calculations

9.2.1 Examination of First vs. Later Years Harvest Dose Contributions ............... 31

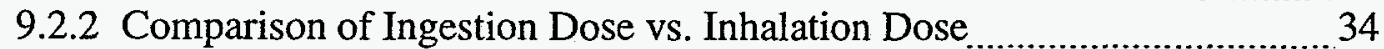

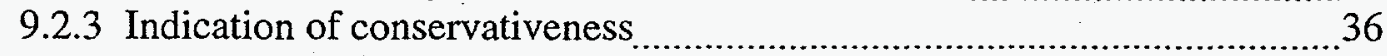

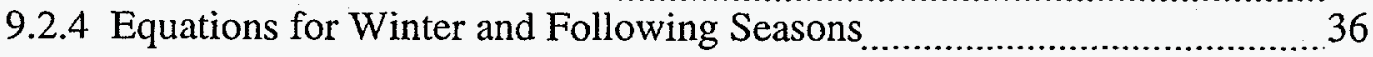

9.2.5 Examination of Tritium Concentrations - AXINGST versus Measured …... 37

9.350 -year Committed Dose Equivalent Factors for Ingestion …..............................39 


\section{LIST OF TABLES}

Table 3-1 Determination of $99.5 \%$ dose in AXAIRQ 6

Table 5-1 Effective biological elimination rates from beef 18

Table 5-2 Biological elimination rates for milk 19

Table 6-1 Vegetable consumption dose from first and second harvests. 20

\section{LIST OF FIGURES}

Figure 3-1 Map of SRS showing the division of the site into sixteen sectors for a centerof-site release 


\subsection{INTRODUCTION}

AXAIRQ is a predictive atmospheric dose model developed and used at the Savannah River Site (SRS) for accident assessment. The SRS is a Department of Energy (DOE) facility located near Aiken, South Carolina, currently managed by Westinghouse Savannah River Company (WSRC). AXAIRQ (Simpkins 1995b, Pillinger and Huang 1986 ) is used to predict the worst-case dose following a hypothetical acute atmospheric release of radionuclides. The model calculates dose due to inhalation, plume shine, and ground shine pathways. The addition of an ingestion model would provide completeness of pathway analysis. Further, as the DOE begins the proposed transition to regulation by the U.S. Nuclear Regulatory Commission (NRC) (Buhl et al. 1997), the addition of an ingestion model in the accident dose model will become necessary to comply with certain NRC regulations (USNRC 1995).

\subsection{OBJECTIVE}

The purpose of this research was to develop, implement, and verify an ingestion model for the accident dose code AXÄIRQ.

\subsection{BACKGROUND}

\subsection{AXAIRQ}

AXAIRQ calculates a predictive dose for both individuals and the population surrounding SRS. It is used predominantly for safety-related documentation and follows the recommendations in USNRC Regulatory Guide 1.145 (USNRC 1982). AXAIRQ uses the Gaussian plume model to describe the hypothetical transport of radionuclides from the release site to the area of interest. The Gaussian plume model, exposure pathways, and method of dose reporting are discussed in more detail below.

Prior to running AXAIRQ, the hypothetical accident parameters must be entered into the code. Input requirements include, but are not limited to, the location of the release, classification of the release as resulting from a stack or vent, mixing height, and the quantity of each radionuclide released. The release is assumed to occur over a minimum 2 hour period. A calendar year for the postulated release is necessary to estimate population dose. The user has the option of including deposition and depletion of the plume, as well as the distances from the release at which to calculate dose (Simpkins 1995a). Default values are available for most input requirements.

AXAIRQ currently consists of six modules, each with various subroutines. The modules of AXAIRQ, in order of use, are (Simpkins 1995b): 
- AXAIN95 reads the user input data, data files, and dose factors. AXAIN95 determines the minimum distance from release location to site boundary in each of the sixteen sectors. Additionally, AXAIN95 determines the percentage of total time the wind is blowing in a given direction, stability class, and wind speed category. The above information is written into temporary files for access by subsequent modules.

- AXATERL constructs an array of concentric rings (out to 50 miles) around the release point representing the maximum relative terrain height. Data is read from an Oak Ridge National Laboratory data base.

- AXAPOP89 calculates the projected 50 mile offsite population, based on year of release, according to sector and distance from the release.

- AXAMET95 calculates the relative air concentrations for all user-specified sectors and distances. Depletion factors are also calculated.

- PRIMUSL determines the radionuclide daughter ingrowth for all nuclides specified.

- AXADOS95 calculates individual and population doses by radionuclide and pathway. Diagrams of the subroutines for each module can be found in Simpkins (1995b).

\subsubsection{Models Used}

Calculating dose following a hypothetical acute atmospheric release requires the use of models to predict the behavior of the radionuclides. Each model represents a specific aspect of the dose calculation. Brief descriptions of some of the models incorporated within AXAIRQ are given below (Simpkins 1995b).

\subsubsection{Meteorological Database}

The meteorological data analyzed in the AXAIN95 submodule are collected from eight weather towers located throughout the SRS. Meteorological data from the weather tower closest to the user-entered release location are used.

The meteorological data are organized as a five-year joint frequency distribution (JFD) containing information on wind speed, atmospheric stability, and wind direction. To determine wind direction, the site is divided into sixteen sectors relative to the release point (Figure 3-1). Wind speed and atmospheric stability are distributed over six and seven categories, respectively. Atmospheric stability is a measure of the turbulence within the atmosphere (NCRP 1984) and is determined by the standard deviations of the lateral or azimuthal wind direction (Simpkins 1995b). The atmospheric stability categories range from very unstable to stable (Simpkins 1995b). 


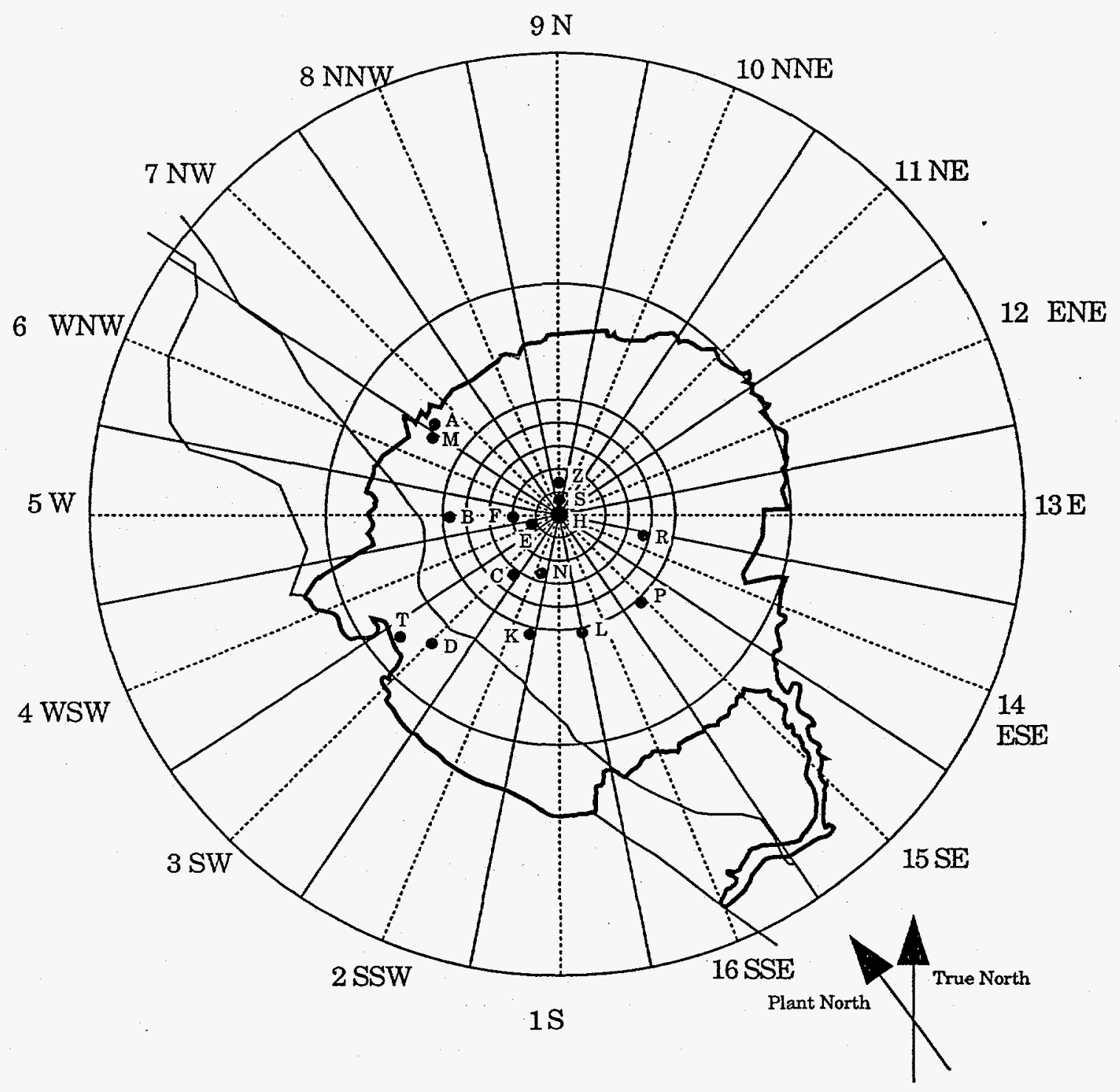

Figure 3-1 Map of SRS showing the division of the site into sixteen sectors for a centerof-site release (Simpkins 1995b). 


\subsubsection{Atmospheric Dispersion}

Estimation of the ground level radionuclide concentration at a given distance from the release point is performed using the Gaussian plume, straight-line trajectory model (Simpkins 1995b). The Gaussian plume model calculates the relative air concentration, $\chi / \mathrm{Q}$, which is defined as the ratio of the plume concentration $\chi\left(\mathrm{Ci} / \mathrm{m}^{3}\right)$ to the source strength $\mathrm{Q}(\mathrm{Ci} / \mathrm{s})$ (Simpkins $1995 \mathrm{~b})$. Based on input data, $\chi / \mathrm{Q}$ is calculated for either a stack or vent release. Centerline relative air concentrations are used in determining dose to the maximally exposed individual (MEI) while sector-arc average concentrations are used to calculate the population dose (Simpkins 1995a).

If a stack release is chosen, meteorological conditions for the release area are examined to determine if non-fumigation or fumigation conditions apply (Simpkins 1995b). Fumigation occurs when the downwind plume is restricted between ground level and the effective inversion height with uniform vertical mixing. Fumigation is considered only under specific atmospheric conditions, and then only for the first half-hour of the release period. For non-fumigation conditions, the centerline relative air concentration is calculated by:

$$
\frac{\chi}{Q}=\frac{1}{2 \pi \sigma_{y} \sigma_{z} U_{H S}}\left[e^{-\left(\frac{\left(z-h_{c}\right)^{2}}{2 \sigma_{z}^{2}}\right)}+e^{-\left(\frac{\left(z+h_{c}\right)^{2}}{2 \sigma_{z}^{2}}\right)}\right]
$$

where:

$\chi / Q \quad$ relative air concentration or dispersion factor $\left(\mathrm{s} / \mathrm{m}^{3}\right)$

$z \quad$ height above the ground surface $(\mathrm{m})$

$h_{e} \quad$ effective release height $(\mathrm{m})$

$U_{H S}^{e} \quad$ wind speed at the release height $(\mathrm{m} / \mathrm{sec})$

$\sigma_{\mathrm{y}}$ standard deviation of the concentration distribution in the horizontal crossplume direction $(\mathrm{m})$

$\sigma_{z} \quad$ standard deviation of the concentration distribution, vertical direction (m)

The standard Gaussian plume model is manipulated to calculate relative air concentrations for vent releases, fumigation conditions, and sector-arc average concentrations (Simpkins 1995a).

The standard deviations of the concentration distribution in the horizontal and vertical directions ( $\sigma_{y}$ and $\sigma_{z}$, respectively) represent the spreading of the plume as it moves downwind. These diffusion coefficients are empirically determined and are functions of atmospheric stability, downwind distance, and surface roughness (NCRP 1984).

\subsubsection{Deposition velocity}

Deposition velocity is considered in the plume depletion and ground shine dose models. Deposition velocity is defined as (NCRP 1984): 


$$
V_{d}=\frac{\omega}{C}=\frac{\text { deposition rate }}{\text { air concentration }}=\frac{\mathrm{Ci} / \mathrm{m}^{2} \mathrm{~s}}{\mathrm{Ci} / \mathrm{m}^{3}}=\frac{\mathrm{m}}{\mathrm{s}}
$$

Although deposition velocity varies with atmospheric and particle parameters, AXAIRQ uses constant values of $0.01 \mathrm{~m} / \mathrm{s}$ for iodines and $0.001 \mathrm{~m} / \mathrm{s}$ for all other particulates (EPA 1991).

\subsubsection{Current Pathways}

Within AXAIRQ, doses due to inhalation, plume shine, and ground shine are directly proportional to the relative air concentration, $\chi / \mathrm{Q}$. The inhalation model uses the relative air concentration at the receptor to calculate the concentration of radionuclides in the inhaled air. Inhalation dose factors and the breathing rate are used to convert the air concentration to inhalation dose. The dose due to plume shine can be calculated using either uniform or non-uniform plume models. Both models use $\chi / Q$ and various modifiers determined by the type of plume model. The ground shine model was adapted from the EPA (1991) model and uses a four day exposure period to account for the ingrowth of short-lived daughters. The relative air concentration is used to determine the amount of radionuclides deposited on the ground surface. Detailed explanations of the calculations for each of these dose pathways can be found in Simpkins (1995b).

\subsubsection{Determination of Reported Dose}

Computation of the reported dose is performed in the AXADOS95 submodule. AXADOS95 computes the maximally exposed individual (MEI) and population doses by radionuclide and pathway. MEI dose estimates are determined for sector dependent doses that are exceeded only $0.5 \%$ of the time in the worst sector ( 99.5 percentile dose). Sector independent individual doses that are exceeded either 5\% (95 percentile) or $50 \%$ (50 percentile) of the time can also be calculated. Population doses are estimated for meteorological conditions for which the dose is exceeded only $0.5 \%$ of the time in the worst sector. All calculated doses resulting from internal assimilation are 50 year committed effective dose equivalent.

The MEI dose that is exceeded only $0.5 \%$ of the time is determined by ranking all calculated doses (sum of inhalation, ground shine and plume shine) for each sector from highest to lowest along with their respective cumulative frequency. In each sector, when the cumulative frequency exceeds the desired fraction $(0.5 \%$ for MEI dose) the model interpolates between this value and the previous value (Table 3-1). After the dose that is exceeded only $0.5 \%$ of the time in each of the 16 sectors has been determined, the highest 
of these values is reported as the worst case, worst sector dose. The same process of ranking the cumulative frequencies of dose resulting from all possible weather combinations in each sector is used in determining the population dose that is exceeded only $0.5 \%$ of the time (Simpkins and Kurzeja 1993). The individual dose for meteorological conditions exceeded only $5 \%$ and $50 \%$ of the time is determined by ranking all values, independent of sector.

Table 3-1. Determination of 99.5\% dose in AXAIRQ (Simpkins and Kurzeja 1993)

$*$\begin{tabular}{|llll|}
\hline Dose & Cumulative & Stability & Wind \\
* rem) & Frequency $(\%)$ & Class & Speed \\
\hline $7.97 \mathrm{E}-04$ & 0.018 & 4 & 1 \\
$7.79 \mathrm{E}-04$ & 0.030 & 5 & 1 \\
$4.43 \mathrm{E}-04$ & 0.091 & 5 & 2 \\
$4.05 \mathrm{E}-04$ & 0.194 & 4 & 2 \\
$4.01 \mathrm{E}-04$ & 0.226 & 3 & 1 \\
$2.68 \mathrm{E}-04$ & 0.297 & 5 & 6 \\
$2.65 \mathrm{E}-04$ & 0.420 & 4 & 6 \\
$2.32 \mathrm{E}-04$ & 0.438 & 6 & 2 \\
$2.27 \mathrm{E}-04$ & 0.612 & 3 & 2 \\
$2.16 \mathrm{E}-04$ & 0.687 & 2 & 1 \\
$1.98 \mathrm{E}-04$ & 0.698 & 4 & 4 \\
$1.79 \mathrm{E}-04$ & 1.072 & 1 & 1 \\
$1.46 \mathrm{E}-04$ & 1.075 & 7 & 2 \\
\hline
\end{tabular}

\subsection{Ingestion Models Available}

A variety of ingestion models have been developed to examine dose following an atmospheric release of radionuclides. Many of these models were designed for chronic releases where an equilibrium concentration is reached between the food chain compartments. For accidental releases, an equilibrium state is not present and different models must be used.

Currently available ingestion models designed for accidental releases were examined for their use with AXAIRQ. Of the models examined, many contained sophisticated modeling and were designed for a specific geographical location. AXAIRQ's calculation of a worst-case dose and its use of the JFD prohibit the incorporation of these models directly into AXAIRQ. Of the models examined, PATHWAY (Kirchner and 
Whicker 1983; Whicker and Kirchner 1987; Whicker et at. 1990), ECOSYS-87 (Müller and Pröhl 1993), and COMIDA (Abbott and Rood 1993, 1994 ) contain aspects desirable for AXAIRQ's ingestion model. A brief summary of these models is given below.

\subsubsection{PATHWAY}

PATHWAY was developed to retrospectively determine dose due to consumption of radionuclide contaminated foodstuffs for the population surrounding the Nevada Test Site (NTS). The contamination resulted from above-ground nuclear tests performed during the 1950's and early 1960's at NTS. PATHWAY dynamically simulates the transport of fallout radionuclides through the agricultural food chain. The model was designed to be realistic, testable, and completely time-dependent (Whicker and Kirchner 1984). The model parameters used are for the arid and semiarid climate of the Southwest, but can be adapted for other climates (Whicker and Kirchner 1987).

PATHWAY independently models pasture, crop, and garden land management units. One or more of each of the land management unit types can be modeled simultaneously. Within each unit, the transport of fallout radionuclides to humans via consumption is divided into six state variables, or compartments, each representing a quantity of radionuclide $\left(\mathrm{Ci} / \mathrm{m}^{2}\right)$. The state variables represent vegetation surface, vegetation internal tissues, soil surface $(0-0.1 \mathrm{~cm})$, labile soil $(0.1-25 \mathrm{~cm})$, fixed soil $(0.1-$ $25 \mathrm{~cm}$ ), and deep soil (>25 cm) (Whicker and Kirchner 1987). Additional compartments depending on the land management type can include pasture grass, alfalfa, grains, garden vegetables, milk, beef, eggs, poultry, stored hay and canned food.

PATHWAY calculates the time dependent concentration of a radionuclide in a given compartment by examining the inflow and outflow from that compartment. This is represented by (Whicker and Kirchner 1987):

$$
\dot{Q_{h}}=\sum_{i=1}^{n} R_{i n, i}-\sum_{j=1}^{m} R_{\text {out }, j}
$$

where:

$Q_{h}^{\prime} \quad$ inventory change in compartment $h$ with respect to time

$R_{i n, i} \quad i$ th inflow rate to $h\left(\mathrm{Ci} \mathrm{m}^{-2} \mathrm{~d}^{-1}\right)$

$R_{\text {out }, j} \quad j$ th outflow rate to $h\left(\mathrm{Ci} \mathrm{m}^{-2} \mathrm{~d}^{-1}\right)$

$n \quad$ number of inflow rates

$m$ number of outflow rates

The time dependent concentration is calculated for each deposited radionuclide and food type. 
PATHWAY uses a combined discrete-continuous model to represent the inflow and outflow of radionuclides between state compartments and foodstuffs. Discrete events are those that occur on specific days and include deposition, soil tillage, crop harvest, and dairy cow diet changes. Continuous events occur without regard to date and are represented by first order differential equations. Continuous events include resuspension, percolation, rainsplash, weathering, adsorption/desorption in soil, leaching from the soil, foliar absorption, root uptake and plant growth, senescence, ingestion and excretion from animal tissue, and radioactive decay (Whicker and Kirchner 1987).

The largest obstacle in the use of PATHWAY with AXAIRQ is its date and time dependence. Since PATHWAY retrospectively examines dose, a calendar date for the release is known. This allows using meteorological and agricultural data specific for the release date and calculation of time dependent concentrations in foodstuffs. In AXAIRQ a release date is not known and instead the JFD is used to calculate a 99.5\% MEI dose. This difference between worst-case (AXAIRQ) and actual (PATHWAY) scenarios prevents the direct use of PATHWAY. However, some portions of PATHWAY will be used.

\subsubsection{COMIDA}

COMIDA (Abbott and Rood 1993) calculates the radionuclide concentration in foodstuffs following an accidental release and is used in the MELCOR Accident Consequence Code System (MACCS). MACCS evaluates multiple randomly-selected fallout dates throughout the calendar year when calculating dose. Thus its' ingestion model is dynamic and capable of modeling the variations resulting from different release times (Abbott and Rood 1994). COMDA is transportable, easy to operate, and requires simple input parameters.

COMIDA is similar to PATHWAY and estimates both the radionuclide concentration in human food crops at yearly intervals and the integrated concentration in animal products. COMIDA examines five human crop foods in addition to milk, beef, poultry, and eggs. To calculate the integral concentration in animal products, COMIDA uses the simplifying assumption that the animal product concentration is an equilibrium fraction of the integrated feed concentration. This results in a conservative bias for animal product concentrations. COMMA defines additional sets of modeling compartments for each decay chain member examined.

The ability to examine seasonal affects on the date of deposition is an important aspect of COMIDA, and is a result of the random selection of deposition dates performed by MACCS. However, AXAIRQ does not consider a specific date of deposition. As a result, only portions of COMIDA will be used with AXAIRQ. 


\subsubsection{ECOSYS-87}

ECOSYS-87 was developed to calculate dose following an accidental atmospheric release of radionuclides (Müller and Pröhl 1993). The model is extremely detailed, including foodstuffs important only for specific groups, and can be used to support decisions concerning countermeasures. ECOSYS-87 examines dose due to ingestion, inhalation, ground shine and plume shine. The parameters used are for Southern Germany but can be changed for other localities.

Like PATHWAY and COMIDA, ECOSYS-87 calculates the time dependent radionuclide concentration in food products. The seasonal variations in crops, animal feeding practices, and human dietary habits are considered. As a result, the time of year in which deposition occurs is important since food chain transfer processes are highly dependent on season (Müller and Pröhl 1993).

ECOSYS-87 examines both wet and dry deposition. Determination of wet deposition requires the amount of rainfall occurring during the fallout event, a parameter not included in the AXAIRQ meteorological data base. The amount of radionuclides deposited on foliage is calculated using the leaf area index (LAI) at the time of deposition. The LAI is specific for each plant species and is directly proportional to the time of year during which the release occurs (Müller and Pröhl 1993). Calculation of root uptake is performed using the transfer factor and assumes that the radionuclides are well mixed within the entire rooting zone.

Although ECOSYS-87 does not meet the requirements for incorporation within AXAIRQ, various aspects of ECOSYS-87 will be used.

\subsection{APPROACH/METHOD}

The development of an ingestion model for AXAIRQ required a multi-step process. The first step was to design a tentative ingestion model based on currently available models and the requirements of AXAIRQ's users. Next, the agricultural practices of the SRS area and the radionuclides potentially released from the SRS were examined. These values were incorporated into the model, and necessary adjustments were made. Finally, the developed ingestion model was verified with available accidental release information.

The ingestion models that were examined for incorporation into AXAIRQ are discussed above. An exact replication of these models could not be used because they do not meet the requirements of AXAIRQ. Additionally, the users of AXAIRQ have specified that the developed ingestion model should be both conservative and simplistic. As a result, all contamination and exposure pathways that contribute less than $10 \%$ of the total ingestion dose were re-examined for necessity and potentially eliminated. 
During the second step, site and area specific variables were defined. Foodstuffs were classified according to their contribution to potential dose from ingestion. For simplicity, the products were grouped according to similar characteristics. Food consumption of the local area was examined, including the percentage of consumed vegetables and animal products produced locally. Current and future missions at the SRS were examined to develop a list of potentially released radionuclides. Concentration and uptake factors were determined for each foodstuff category and radionuclide.

In the final step, the ingestion model was verified. Hand calculations were performed to verify the significance of dose contribution for each contamination pathway and the proper use of methodologies. Validation of the foodstuff concentration portion of the model also was performed. Foodstuff concentration data from previous acute atmospheric releases occurring at the SRS were compared with that calculated using the AXAIRQ ingestion model for the same source term.

\subsection{RESULTS}

The ingestion model developed for AXAIRQ, named AXINGST, is based on the models discussed above. AXINGST examines the transport and fate of radionuclides from deposition to human consumption. This includes both human food crops and animals products. AXINGST has been developed to be conservative and simplistic, and includes only pertinent contamination and exposure pathways. Where possible, site specific information has been used.

AXINGST independently examines dose resulting from consumption of contaminated vegetables, meat, and milk. Human food crops and pasture/hay land-use systems are treated independently due to differences in harvesting. A description of the three routes for ingestion dose follows. A summary of all equations and variables used in AXINGST can be found in Appendix 9.1.

\section{I Radionuclide Intake from Vegetables}

This segment calculates the radionuclide quantity ingested as a result of vegetable consumption.

\subsubsection{Initial Crop Contamination}

The ingestion models examined for incorporation into AXAIRQ are dependent on the deposition date. Since accidents can occur any time of the year, and accident dates are not known for prospective dose assessments, AXAIRQ is not date dependent. Also, use of the JFD meteorological data prevents knowing the weather conditions for any particular 
day. Since AXAIRQ is predominantly used to show compliance with regulations, use of a worst-case deposition scheme would be preferable. As a result, AXINGST will not be designed as date dependent.

For single deposits, Simmonds and Linsley (1982) suggest designing the model such that deposition is close to harvest. If deposition and harvest occur close in time, it can be assumed that loss due to transfer processes does not occur. Additionally, this will usually result in the maximum contamination in food crops (Simmonds and Linsley 1982). Since a worst-case situation is appropriate for showing compliance, deposition onto food crops will occur on the day of harvest.

The amount of activity deposited from the plume onto the ground surface is directly dependent upon the radionuclide concentration in the plume $(\chi)$, the deposition rate for the given radionuclide $\left(V_{d}\right)$, and the length of time the deposition occurs $\left(t_{\text {dep }}\right)$. The deposition time period is assumed equivalent to the user entered length of release. The amount of radionuclide deposited at a given location in a given sector is calculated by (Napier et al. 1988):

$$
D E P=\chi * V_{d} * t_{d e p}
$$

where:

$$
\begin{array}{ll}
\text { DEP } & \text { amount deposited on surface }\left(\mathrm{Ci} / \mathrm{m}^{2}\right) \\
\chi & \text { relative air concentration }\left(\mathrm{Ci} / \mathrm{m}^{3}\right) \\
V_{d} & \text { deposition velocity (EPA 1991) } \\
& 0.01 \mathrm{~m} / \mathrm{s} \text { for iodines } \\
& 0.001 \mathrm{~m} / \mathrm{s} \text { for particulates } \\
t_{\text {dep }} & \text { deposition time (s) }
\end{array}
$$

The amount deposited at any given location will vary with sector and distance from release.

Wet deposition is not considered in AXINGST. USNRC Reg. Guide 1.111 (1977) indicates that wet deposition should be considered for sites having a well-defined rainy season concurrent with the grazing season. SRS does not have a well-defined rainy season (Hamby 1992).

The activity deposited from the plume is divided between the vegetation surface and soil surface compartments. The interception factor $(f)$ is an empirical relationship, developed by Chamberlain (1970), relating vegetation biomass and the fraction of deposit intercepted by the vegetation. The percentage of total deposit intercepted by the vegetation surface $\left(f_{v}\right)$ and soil surface $\left(f_{s}\right)$ is calculated by (Whicker and Kirchner 1987):

where:

$$
\begin{aligned}
& f_{v}=1-e^{-\alpha B^{\prime}} \\
& f_{s}=1-f_{v}=e^{-\alpha B^{\prime}}
\end{aligned}
$$

$\alpha$ foliar interception constant

$$
2.9 \mathrm{~m}^{2} / \mathrm{kg}
$$


$\mathrm{B}^{\prime} \quad$ standing crop biomass at time of deposition (dry $\mathrm{kg} / \mathrm{m}^{2}$ )

$0.45 \mathrm{~kg} / \mathrm{m}^{2}$ pasture grass

$0.19 \mathrm{~kg} / \mathrm{m}^{2}$ leafy vegetables

$0.11 \mathrm{~kg} / \mathrm{m}^{2}$ fruit and other vegetables

In some models, a separate foliar interception constant is used for fruits and nonleafy vegetables. Pinder et al. (1988) suggest the increase in the foliar interception constant for certain vegetation types may be a result of the uncertainty in determination of total deposit. An increase in the foliar interception constant affects the interception fraction minimally, and thus only one value is used. Since deposition and harvest occur on the dame day, biomass at time of deposition is calculated from local agricultural productivity values (1.8 wet $\mathrm{kg} / \mathrm{m}^{2}$ pasture grass, 0.7 wet $\mathrm{kg} / \mathrm{m}^{2}$ vegetables, Hamby 1991) and converted to dry weight (0.25 pasture grass (Hamby 1991), 0.27 leafy vegetables, 0.15 fruit and other vegetables (Whicker and Kirchner 1987)).

The initial contamination of the vegetation and soil surfaces is calculated as the product of the total deposit and the corresponding interception fraction (Eqn 5-4).

where:

$$
C_{v}^{o}=D E P * f_{v} \text { and } C_{s}^{o}=D E P * f_{s}
$$

$C_{v}^{o} \quad$ initial vegetation contamination $\left(\mathrm{Ci} / \mathrm{m}^{2}\right)$

$C_{s}^{o} \quad$ initial surface soil contamination $\left(\mathrm{Ci} / \mathrm{m}^{2}\right)$

Since harvest occurs on the day of deposition, the same inventory is present at harvest. To calculate the radionuclide concentration at harvest, the plant inventory is divided by the amount harvested (Eqn 5-5). The agricultural productivity in the SRS area used in AXINGST is $0.70 \mathrm{~kg} / \mathrm{m}^{2}$ (wet) for both leafy and other vegetables (Hamby 1991).

$$
C_{v}^{h}=\frac{C_{v}^{o}}{B}
$$

$C_{v}^{h} \quad$ concentration at harvest $(\mathrm{Ci} / \mathrm{kg})$

B agricultural productivity (Hamby 1991)

\subsubsection{Concentration in Following Years Crop}

To meet the goals of AXAIRQ's users, AXINGST has been made as simplistic as possible without a large sacrifice in accuracy. To accomplish this, pathways that represent less than $10 \%$ of the total ingestion dose have been reexamined for importance. Since harvest of food crops occurs on the day of deposition, the largest percentage of the ingestion dose is from consumption of this vegetation.

In thelocal region, growth of above-ground vegetables requires approximately 70 days (Hamby 1991), resulting in 290 days for the radionuclides to redistribute within the soil depth. During this time, percolation removes essentially all of the surface soil 
radionuclides, drastically reducing the surface contamination of vegetables due to resuspension and rainsplash. Later years harvests are thus predominantly contaminated due to root uptake. However, Sprung et al. (1990), indicate that of the radionuclides deposited onto soil, less than $1 \%$ will be consumed by man as a result of long-term root uptake. Since this amount is far less than that consumed from the first year harvest, subsequent years harvests will not be considered.

\subsubsection{Calculation of Intake}

After harvest, the concentration of radionuclides in human food crops is affected by storage and processing or preparation. While vegetables are stored, radiological decay results in a decrease in radionuclide content. Preparation and processing of vegetables, including washing and peeling, also decrease the radionuclide inventory in vegetables. In AXINGST, the preparation and processing modifier includes removal of unedible portions of the vegetables (e.g. corn husks) and transfer of surface deposits to internal tissues. The values used are a combination of multiple modifiers in COMIDA (Abbott and Rood 1993) and are constant for all radionuclides.

The concentration in human crop foods at the time of consumption is calculated by (Whicker and Kirchner 1987; Müller and Pröhl 1993; Abbott and Rood 1993):

$$
C_{v}^{c}=C_{v}^{h} f_{p} e^{-\lambda_{r} t}
$$

where:

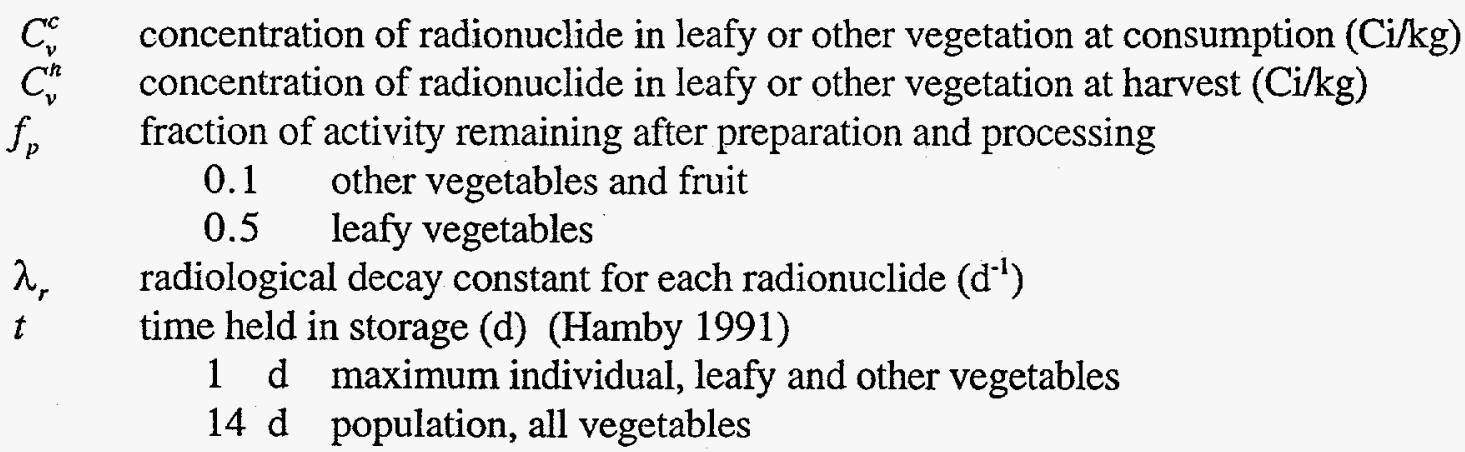

The quantity of radionuclide ingested with human food crops is dependent upon the concentration of the radionuclides in vegetation at time of consumption (Eqn 5-5) and the amount consumed. For dose due to vegetable consumption, all members of the population are assumed to be adults. Hamby (1991) separates human crop food into two vegetable categories, leafy and other. The average adult individual in the SRS region consumes 21 $\mathrm{kg} / \mathrm{yr}$ of leafy vegetables and $163 \mathrm{~kg} / \mathrm{yr}$ of other vegetables. Area grocery stores receive nearly all of their food from central distribution warehouses and sell local food only when warehouses do not send enough or consumers request a specific local food (Twining et al. 
1996). Considering this, AXINGST assumes the average individual consumes $5 \%$ locally produced leafy and other vegetables. The MEI consumes $43 \mathrm{~kg} / \mathrm{yr}$ leafy vegetables and $276 \mathrm{~kg} / \mathrm{yr}$ other vegetables of which $100 \%$ and $76 \%$, respectively, are produced locally (Hamby 1991). However, were an accident to occur, consumption of contaminated vegetation would be limited to only a few days post deposition. This would be a result of both consumption restrictions determined by governing agencies and the individuals choice not to consume vegetables once an accident has been reported. To allow time for informing nearby residents, AXINGST assumes that the MEI consumes contaminated vegetables for 5 days. Therefore, consumption values for contaminated crops during the first year post deposition are: $0.59 \mathrm{~kg}$ MEI leafy; $3.8 \mathrm{~kg}$ MEI other vegetables; $0.29 \mathrm{~kg}$ population leafy; and $2.2 \mathrm{~kg}$ population other vegetables.

\subsubsection{Tritium Concentration in Vegetables}

AXAIRQ assumes that all tritium is in its oxide form, HTO (Simpkins 1995b). The uptake of tritium by plants occurs via two pathways, root uptake and foliar absorption. Direct uptake via foliar absorption involves the exchange of HTO with circulating water and occurs through the plant stomata. For short time periods foliar absorption is the dominant pathway.

Complex models have been developed that specifically examine the movement of tritium within the environment following an accidental release (Raskob 1991). For use in AXINGST, a more simplistic model is desired. The transfer of HTO exchanged between plants and the atmosphere can vary with temperature, inorganic content, and transfer resistance (Anspaugh et al. 1973). One method to determine this transfer is the the use of the uptake coefficient. The uptake coefficient is defined as the ratio of the tritium concentration in plant tissue water to that of the tritium concentration in the water vapor to which the plant was exposed. For exposure periods of 30 and 60 minutes, Koranda and Martin (1973) found uptake coefficients ranging from 0.17 (black pine) to 0.49 (sunflower). Additionally, uptake factors in each species were the same for both exposure lengths (Koranda and Martin 1973).

The uptake of atmospheric HTO by leaves is rapid, reaching plateau levels in less than thirty minutes (Anspaugh et al. 1973). For predictive models, Anspaugh et al. (1973) use a conservative uptake coefficient of 0.5. Studies at SRS indicate a site applicable uptake coefficient of 0.54 (Hamby and Bauer 1994). The concentration of tritiated water in plants is thus directly dependent upon the concentration of tritiated water in the atmosphere. This is determined by dividing the atmospheric air concentration $(\chi)$ by the absolute 
humidity. The concentration of tritiated water in plants during exposure is therefore calculated by:

where:

$$
C_{v}^{o}=\frac{R * \chi}{H}
$$

$$
\begin{array}{ll}
C_{v}^{o} & \text { initial concentration of tritiated water in vegetables }(\mathrm{pCi} / \mathrm{mL}) \\
\chi & \text { concentration of tritiated water in atmosphere }\left(\mathrm{pCi} / \mathrm{m}^{3}\right) \\
\mathrm{R} & \text { uptake coefficient; } 0.54(\text { Hamby and Bauer } 1994) \\
H & \text { absolute humidity }\left(\mathrm{mL} / \mathrm{m}^{3}\right)
\end{array}
$$

The annual average absolute humidity determined for the SRS is $11.4 \mathrm{~mL} / \mathrm{m}^{3}$ (Arnett 1996).

To examine the decrease in HTO in vegetables after exposure ceases, Anspaugh et al. (1973) calculate the integral half-life of tritiated water in plants, which was found to be 1 day. The integral half life is the "half-life of a single exponential function that has the same integral as the sum of the integrals of the observed components (Anspaugh et al. 1973)." Thus, the vegetation tritiated water concentration after exposure is calculated by:

$$
C_{v}=C_{v}^{o} e^{-\lambda_{p} t}
$$

where:

$$
\begin{array}{ll}
\lambda_{\mathrm{p}} & \text { disappearance rate constant of }{ }^{3} \mathrm{H} \text { in vegetable water }\left(\mathrm{d}^{-1}\right) \\
t & \text { time since exposure ceased (d) }
\end{array}
$$

Since AXINGST models food crops such that deposition and harvest occur on the same day, it is assumed that twelve hours pass between the cessation of exposure and harvest. To calculate the concentration of tritium in the whole plant, the concentration of tritiated water is multiplied by the ratio of water mass to total plant mass (Eqn 5-9).

$$
C_{v}^{h^{\prime}}=C_{v}^{h} * W
$$

$C_{v}^{h^{\prime}} \quad$ concentration of tritium in vegetation ( $\mathrm{pCi} / \mathrm{g}$ )

W ratio of water mass to total plant mass ( $\mathrm{g}$ water / $\mathrm{g}$ total plant mass)

0.75 pasture grass (Hamby 1991); 0.73 leafy vegetables and 0.85 fruit and other vegetables (Whicker and Kirchner 1987)

After the concentration of tritiated water in the vegetation has been determined, the model set forth for other radionuclides is used, with one exception. Since the tritium contamination is not surficial, it is assumed that no removal of contaminants occurs due to preparation and processing of the vegetation. 


\subsection{Radionuclide Intake from Meat}

In addition to vegetables, consumption of contaminated meat contributes to the ingestion dose. Since animal products are not directly exposed to fallout radionuclides, the concentration in pasture and other feed is necessary to determine meat concentration. The only meat type considered in AXINGST is beef. Although hogs, chicken and cattle are the predominant livestock surrounding SRS; only cattle are fed locally produced food (Hamby 1991). As a result, AXINGST assumes that local pork, chicken and eggs will not be contaminated after an SRS release.

\subsubsection{Concentration in Feed and Soil}

Pasture grass must be modeled differently than human food crops due to differences in harvesting. Unlike food crops which have a discrete harvest date, pasture grass undergoes continuous harvesting in the form of animal grazing. The resulting decrease in pasture grass radionuclide concentration can be represented by growth dilution. ECOSYS-87 (Müller and Pröhl 1993) considers both growth dilution and the transfer of mobile elements (e.g. iodine and cesium) within the phloem to the roots with subsequent remobilization. The pasture grass concentration is calculated by:

$$
C_{g, i}(t)=\frac{Q_{v s, g}^{0}}{B_{g}}\left\{(1-a) e^{-\left(\lambda_{b}+\lambda_{w}+\lambda_{r}\right) t}+a e^{-\left(\lambda_{t}+\lambda_{r}\right) t}\right\}
$$

where:

$$
\begin{array}{ll}
C_{g, i}(t) & \text { activity concentration in grass at time } t \text { after deposition }(\mathrm{Ci} / \mathrm{kg}) \\
t & \text { days post deposition (d) } \\
Q_{v s, g}^{0} & \text { total activity deposited onto grass surface }\left(\mathrm{Ci} / \mathrm{m}^{2}\right) \\
B_{g} & \text { grass biomass at time of deposition (wet } \left.\mathrm{kg} / \mathrm{m}^{2}\right) \\
a & 1.8 \mathrm{~kg} / \mathrm{m}^{2} \text { (Hamby 1991) } \\
& \text { fraction of activity translocated to the root zone and remobilized } \\
\lambda_{b} & 0.05 \text { (Müller and Pröhl 1993) } \\
\lambda_{t} & \text { dilution rate by increase of biomass }\left(\mathrm{d}^{-1}\right) \\
& 2.81 \times 10^{-2} \mathrm{~d}^{-1} \text { (Müller and Pröhl 1993; average of year) } \\
\lambda_{\mathrm{w}} & \text { rate of activity decrease due to translocation to the root zone }\left(\mathrm{d}^{-1}\right) \\
& 1.16 \times 10^{-2} \mathrm{~d}^{-1} \text { (Müller and Pröhl 1993) } \\
& \text { loss rate due to weathering } \\
4.95 \times 10^{-2} \mathrm{~d}^{-1} \text { particulates, tritium (Whicker and Kirchner 1987) } \\
7.65 \times 10^{-2} \mathrm{~d}^{-1} \text { iodines (Whicker and Kirchner 1987) }
\end{array}
$$

The total activity deposited onto the grass surface $\left(Q_{v s, g}^{0}\right)$ is calculated in a manner identical to that for vegetable surfaces. 
While grazing, cattle also consume contaminated surface soil. The assumed soil ingestion rate for cows (both beef and dairy) is $0.5 \mathrm{~kg} /$ day (Whicker and Kirchner 1987; Abbott and Rood 1993). The concentration of the soil at a given time post deposition is calculated by:

$$
C_{s}(t)=\frac{Q_{s s}^{0}}{x_{l} p_{l}} e^{-\left(\lambda_{p}+\lambda_{r}\right) t}+\frac{Q_{v s, g}^{0}}{B_{g}}\left(1-e^{-\left(\lambda_{w}\right) t}\right)\left(e^{-\lambda_{f} t}\right)(1-a)
$$

where:

$$
\begin{array}{ll}
C_{s} & \text { activity concentration in the surface soil at time } t \text { after deposition }(\mathrm{Ci} / \mathrm{kg}) \\
Q_{s s}^{0} & \text { total activity deposited onto soil surface }\left(\mathrm{Ci} / \mathrm{m}^{2}\right) \\
x_{l} & \text { depth of soil surface layer subject to ingestion } \\
& 1.0 \times 10^{-3} \mathrm{~m} \\
p_{l} & \text { bulk density of surface soil } \\
& 1.6 \times 10^{3} \mathrm{~kg} / \mathrm{m}^{3} \text { (Looney et al. 1987) } \\
\lambda_{p} & \text { rate constant for percolation out of soil surface } \\
& 1.98 \times 10^{-2} \mathrm{~d}^{-1} \text { (Anspaugh et al. 1975) }
\end{array}
$$

Percolation removes contaminants from the surface soil making the radionuclides unavailable for uptake through soil consumption. PATHWAY (Whicker and Kirchner 1987) uses a percolation half-time of 35 days based on studies performed on western desert soils. Anspaugh et al. (1975) graphically depict the redistribution of plutonium in soil at Nevada Test Site, Rocky Flats, and Livermore. Percolation was similar between NTS and Rocky Flats, but significantly faster at Livermore. The increased percolation rate at Livermore led to speculation that eastern U.S. soils would also experience a faster percolation rate, although a value was not given. However, a percolation rate specific for SRS was not obtained and thus the slower half-time of 35 days will be used in AXINGST.

In addition to pasture grazing, beef cattle also consume a small portion of stored feed. In the local area, the storage time for feed ranges from one month to two years. The NRC stored-feed hold-up time of 90 days is considered to be relatively conservative and is recommended for use (Hamby 1991). AXINGST assumes that stored feed is uncontaminated since the maximum concentration in animal tissue will be reached prior to 90 days post deposition, when contaminated stored feed begins to be consumed.

\subsubsection{Concentration in Meat}

Models currently in use to determine the concentration of radionuclides in meat following an accidental release typically assume that the animal product concentrations are in equilibrium with the consumed vegetation and soil (Abbott and Rood 1993). The concentration in beef (or other animal product) depends upon the radionuclide concentration 
in the ingested feed and soil, the transfer factor from feed to animal product, and the biological elimination rate. The concentration in beef or other animal product is calculated by (Müller and Pröhl 1993):

$$
C_{m}(T)=T F_{m}\left\{\int_{0}^{T} A(t) \lambda_{b, m} * e^{-\left(\lambda_{b, m}+\lambda_{r}\right)(T-t)} d t\right\}
$$

where:

$C_{m}(T) \quad$ activity concentration in animal product $m$ at time $\mathrm{T}(\mathrm{Ci} / \mathrm{kg})$

$T F_{m} \quad$ feed transfer factor for animal product $m(\mathrm{~d} / \mathrm{kg})$

$\lambda_{b, m} \quad$ biological elimination rate for animal product $m\left(\mathrm{~d}^{-1}\right)$

$A(t) \quad$ activity intake rate of the animal on day $t(\mathrm{Ci} / \mathrm{d})$

AXINGST assumes the cattle are slaughtered 10 days post deposition, resulting in a 10 day integration time. The integral in Eqn (5-12) is solved using the trapezoid rule (Beyer 1981). Table 5-1 lists effective biological elimination rates from beef for various radionuclides (Müller and Pröhl 1993). For radionuclides not listed in Table 5-1, the biological elimination rate for man will be used (ICRP78). The animal activity intake rate is calculated by:

$$
A(t)=C_{s}(t) I_{s}+C_{g}(t) I_{g}
$$

where:

$C(t) \quad$ activity concentration in soil (s) or pasture grass $(\mathrm{g})(\mathrm{Ci} / \mathrm{kg})$

$I(t) \quad$ daily intake rate for pasture grass $(\mathrm{g})$ or soil $(\mathrm{s})(\mathrm{kg} / \mathrm{d})$

Cattle in the SRS area graze year-round on fresh, coastal bermuda grass. Local beef cattle consume approximately $36 \mathrm{~kg} / \mathrm{day}$, consisting of $75 \%$ pasture grass and $25 \%$ stored grass (Hamby 1991).

\begin{tabular}{|c|c|c|c|c|c|}
\hline Element & $\lambda_{b, m}\left(d^{-1}\right)$ & Element & $\lambda_{\mathrm{b}, \mathrm{ml}}\left(\mathrm{d}^{-1}\right)$ & Element & $\lambda_{b, m}\left(d^{-1}\right)$ \\
\hline Cesium & $1.4 \mathrm{E}-2$ & Zirconium & $8.7 \mathrm{E}-5$ & Cerium & $1.7 \mathrm{E}-4$ \\
\hline Strontium & $1.9 \mathrm{E}-2$ & Niobium & $6.9 \mathrm{E}-3$ & Plutonium & $9.9 \mathrm{E}-5$ \\
\hline Barium & $1.9 \mathrm{E}-2$ & Tellurium & $3.6 \mathrm{E}-3$ & Manganese & $7.5 \mathrm{E}-3$ \\
\hline Iodine & $6.9 \mathrm{E}-3$ & Ruthenium & $2.9 \mathrm{E}-3$ & Zinc & $9.9 \mathrm{E}-4$ \\
\hline
\end{tabular}

Table 5-1. Effective biological elimination rates from beef (Müller and Pröhl 1993)

The transfer factor is the "fraction of the nuclide ingested daily by an animal that is found in $1 \mathrm{~kg}$ of muscle (or other edible product) from the animal under steady-state or equilibrium conditions (NCRP 1984)". Although equilibrium conditions will not exist in the short-term following an accident, the transfer factors are numerically identical for both conditions (Peterson 1983). The transfer factors used in AXINGST are those found in USNRC Regulatory Guide 1.109 (1977). Although updated transfer factors have been 
published since the issue of Reg Guide 1.109, these have not been incorporated into regulations.

\subsubsection{Calculation of intake}

The amount of radionuclide ingested by humans is dependent upon the radionuclide concentration in the beef and the amount of beef consumed. Local beef consumption has been determined to be $81 \mathrm{~kg} / \mathrm{yr}$ for the MEI and $43 \mathrm{~kg} / \mathrm{yr}$ for the average individual (Hamby 1991). Additionally, the transport time between slaughter and consumption is considered to be six days (Hamby 1991). For population doses, only $2 \%$ of the beef consumed is locally produced (Twining et al. 1996). All beef consumed by the MEI is assumed to be contaminated.

\subsection{Radionuclide Intake from Milk}

Calculation of the radionuclide concentration in milk is essentially the same as that for beef. Concentrations in pasture grass, stored feed and soil are described above. The concentration in milk is calculated using Eqn (5-12) and Eqn (5-13) with biological elimination rates and transfer factors appropriate for milk. The biological elimination rates for cow milk are shown in Table 5-2. Transfer factors for milk are taken from USNRC Reg Guide 1.109.

Local dairy cattle consume approximately $52 \mathrm{~kg} / \mathrm{d}$ of food. Of this amount, $56 \%$ is pasture grass, 25\% silage, and 19\% commercial grain (Hamby 1991). Grass and stored feed are produced locally while other portions of the cow feed are usually imported (Twining et al. 1996).

Table 5-2. Biological elimination rates for milk (Müller and Pröhl 1993)

\begin{tabular}{|ll|ll|ll|}
\hline Element & $\lambda_{\mathrm{m}, \mathrm{m}}\left(\mathbf{d}^{-1}\right)$ & Element & $\lambda_{\mathrm{m}, \mathrm{m}}\left(\mathbf{d}^{-1}\right)$ & Element & $\lambda_{\mathrm{m}, \mathrm{m}}\left(\mathbf{d}^{-1}\right)$ \\
\hline Cesium & $3.8 \mathrm{E}-1$ & Zirconium & $6.9 \mathrm{E}-1$ & Cerium & $6.9 \mathrm{E}-1$ \\
Strontium & $2.1 \mathrm{E}-1$ & Niobium & $6.9 \mathrm{E}-1$ & Plutonium & $9.9 \mathrm{E}-5$ \\
Barium & $2.1 \mathrm{E}-1$ & Tellurium & $6.9 \mathrm{E}-1$ & Manganese & $7.5 \mathrm{E}-3$ \\
Iodine & $9.9 \mathrm{E}-1$ & Ruthenium & $2.9 \mathrm{E}-3$ & Zinc & $5.4 \mathrm{E}-2$ \\
\hline
\end{tabular}

Human consumption of milk in the SRS region was found to be $230 \mathrm{~L} / \mathrm{yr}$ for the MEI and $120 \mathrm{~L} / \mathrm{yr}$ for the average person (Hamby 1991). Milk collected in the region is shipped to centrally located processing plants (Twining et al. 1996; Hamby 1991). Locally produced milk is then combined with milk from other areas and shipped throughout the Southeast, including the SRS area. This results in a dilution of the contaminated milk 
(Twining et al. 1996; Hamby 1991). For population calculations, AXINGST uses a conservative assumption that $5 \%$ of milk consumed is contaminated. This assumption accounts for both the mixing of contaminated milk with non-contaminated milk, and the redistribution of this milk throughout the southeast. Additionally, a storage time of 3 days is used in the population dose to account for the shipping time between milking and availability for consumption (Hamby 1991). Corresponding to the consumption restrictions mentioned for vegetable intake, AXINGST assumes that contaminated milk is consumed by the MEI for only 5 days following the accident, resulting in an intake of $3.15 \mathrm{~L}$.

\subsection{Determination of Daughter Ingrowth}

As radionuclides decay, radioactive daughter products also contribute to the ingestion dose. This is mainly important for short-lived radionuclides, since the design of AXINGST reduces the importance of daughter products for long-lived radionuclides.

AXAIRQ currently examines daughter ingrowth in the PRIMUSL subroutine. Daughter ingrowth is calculated during the travel time between the release location and the receptor (Hermann et al. 1984). The released radionuclides and the daughters present at the time the plume reaches the receptor are then analyzed to determine inhalation, plume shine, and ground shine doses. For calculation of the ingestion dose, PRIMUSL will be adjusted to account for the ingrowth occurring during the vegetable hold time. In addition to the plume travel time, an additional 1 day and 14 days of daughter ingrowth will be examined for MEI and population dose, respectively. At the discretion of the programmer, an examination can be performed using PRIMUSL to determine the effects of daughter ingrowth on the ingestion dose. If, using the accident scenarios used at the SRS, daughter ingrowth is found to contribute less than $10 \%$ of the dose, then the additional ingrowth can be eliminated.

\subsection{Calculation of ingestion dose}

The ingestion dose is calculated by multiplying the total quantity of each radionuclide ingested by its ingestion dose factor and summing the partial doses. The total quantity ingested is the sum of the vegetable, meat and milk quantities. The ingestion dose factors are the DOE values found in USDOE (1988). Appendix 9.4 lists the values for the radionuclides modeled in AXINGST. 


\subsection{DISCUSSION}

To coincide with the purpose and use of AXAIRQ, the ingestion model AXINGST needs to be conservative and simplistic.

One method used was to model AXINGST such that, for human food crops, harvest and deposition occur on the same day. This results in a highly conservative dose from crops harvested during the deposition year. Appendix 9.3.1 shows the MEI and average individual (representative of the population) dose calculations for a release of $1 \mathrm{Ci}$ each of Cs-137 and I-125 from the center of site. Additionally, an examination of the dose resulting from the following years crop was also performed. As modeled, the second year crops were found to contribute $<5 \%$ of the initial years dose (Table 6-1). It is evident that, compared to the initial harvest, the dose from subsequent harvests is minimal and can be excluded from AXINGST.

Table 6-1 Vegetable consumption dose from first and second harvests (mrem)

\begin{tabular}{|l|c|c|c|c|}
\hline & MEI: Cs-137 & MEI: I-125 & Avg: Cs-137 & Avg: I-125 \\
\hline First Harvest & $7.4 \mathrm{E}-2$ & $5.6 \mathrm{E}-1$ & $6.5 \mathrm{E}-2$ & $4.2 \mathrm{E}-1$ \\
Second Harvest & $1.0 \mathrm{E}-3$ & $1.2 \mathrm{E}-4$ & $1.4 \mathrm{E}-5$ & $1.1 \mathrm{E}-5$ \\
\hline \% of First Year & 1.4 & 0.0065 & 0.022 & 0.0026 \\
\hline
\end{tabular}

To examine the treatment of tritium in AXINGST, calculated values were compared to measured values obtained following accidental tritium releases (Murphy and Wortham 1997). A comparison of six accidents occurring between March 1981 and March 1985 indicates that, using the $99.5 \% \chi / \mathrm{Q}$, AXINGST over-predicts the vegetation tritium concentration by a factor between 100-2000, with most values near 250 (Appendix 9.3.3). Hand calculations of the $\chi / Q$ and resulting vegetation concentration based on information obtained from Murphy and Wortham (1997) indicate a vegetation concentration overprediction between $20-40$ fold.

The addition of AXINGST to AXAIRQ will result in an increase in reported dose. To determine the extent of this increase, hypothetical releases of $4 \mathrm{Ci} \mathrm{Cs}-137$ and $2 \mathrm{Ci}$ I135 were examined (Appendix 9.2.2). For the Cs-137 release, the addition of the ingestion pathway resulted in a 200 fold increase in reported dose for the MEI. Dose codes for MEI dose following routine releases at the SRS indicate a comparable increase in dose for ingestion of Cs-137. The dose increase for I-135 was approximately 100 fold. Due to the short half-life of I-135 (6.585 hours), this dose increase can be significantly reduced by holding the vegetables for approximately 3 days prior to consumption. 
To indicate the conservativeness of this model, the above MEI Cs-137 calculations were compared with more realistic calculations. In the more realistic situation, the individual of concern was assumed to live on the boundary of the SRS, similar to the MEI, but consume food products at the rate of the average individual (Appendix 9.2.3). Additionally, the $95 \% \chi / \mathrm{Q}$ was used." Although still conservative, the $95 \% \chi / \mathrm{Q}$ is less so than the $99.5 \%$. The calculated dose for this more realistic scenario was a factor of 50 less than that for the MEI. The 50 fold difference between the MEI (99.5\%) and the more realistic (95\%) dose was also seen for each of the four food products examined. Furthermore, if the $50 \% \chi / \mathrm{Q}$ were used in this scenario instead of the $99.5 \%$ the reduction in ingestion dose to this individual of concern would be greater.

Throughout the development of AXINGST two principals have been sought, simplicity and conservativeness. The simplicity in AXINGST has been achieved by eliminating pathways that contribute little to the total dose, such as harvests from subsequent seasons. The conservativeness of the ingestion model can be seen in the calculations discussed above. For MEI calculations, especially for long-lived radionuclides, the calculated dose is at least a factor of 50 higher than a more realistic, but still conservative dose. Additionally, the calculated tritium concentrations have been found to exceed those measured, indicating a conservative modeling approach for tritium.

The addition of AXINGST to AXAIRQ will increase the reported dose. The amount of increase will vary by radionuclide, with the half-life a large determinant. Despite the increased reported dose, an ingestion model is necessary for AXAIRQ, and the developed model meets the purpose of AXAIRQ and the requirements of its users.

\subsection{CONCLUSION}

The ingestion model, AXINGST, has been developed for use with the Savannah River Site accident dose code AXAIRQ. For simplicity and to ensure the model is conservative, AXINGST assumes that radionuclide deposition and harvest of human food crops occur on the same day. This assumption is highly conservative and dose from subsequent harvests is not considered. The addition of AXINGST to AXAIRQ would increases the reported dose by a factor of roughly 200 for long-lived particulate radionuclides such as Cs-137. For short lived radionuclides such as I-135, this could be reduced to approximately a 100 fold increase, and can be further reduced by storing vegetables for a short time period. Consumption values used for the MEI compared to the average individual, and use of the $99.5 \% \chi / \mathrm{Q}$ instead of a less conservative $95 \% \chi / \mathrm{Q}$, result in at least a 50 fold increase in dose. Users should realize that the MEI calculations in AXINGST are conservative but do indicate the maximum possible dose. Incorporation 
of AXINGST into AXAIRQ may require additional communication with regulatory agencies to convey the conservatisms in this model. The ingestion dose can be drastically reduced by instructing the public not to consume local food products. 


\subsection{REFERENCES}

Abbott, M.L.; Rood, A.S. COMIDA: A radionuclide food-chain model for acute fallout deposition. Idaho Falls, ID: Idaho National Engineering Laboratory; EGG-GEO$10367 ; 1993$.

Abbott, M.L.; Rood, A.S. COMIDA: A radionuclide food chain model for acute fallout deposition. Health Physics 66: 17-29; 1994.

Anspaugh, L.R.; Koranda, J.J.; Robison, W.L.; Martin, J.R. The dose to man via foodchain transfer resulting from exposure to tritiated water vapor. In: Moghissi, A.A.; Carter, M.W., eds. Tritium. Pheonix, AZ: Messenger Graphics; 1973.

Anspaugh, L.R.; Shinn, J.H.; Phelps, P.L.; Kennedy, N.C. Resuspension and redistribution of plutonium in soils. Health Physics: 29: 571-582; 1975.

Arnett, M.W., ed. Savannah River Site Environmental Data for 1995. Aiken, SC: Westinghouse Savannah River Company; WSRC-TR-96-0077; 1996.

Beas III, C.F.; Sharp, R.D.; Sjoreen, A.L.; Shor, R.W. A review and analysis of parameters for assessing transport of environmentally released radionuclides through agriculture. Oak Ridge, TN: Oak Ridge National Laboratory; ORNL-5786; 1984.

Beyer, W.H., ed. CRC standard mathematical tables, 26th edition. Boca Raton, Fl: CRC Press; 1981.

Buhl, A.R.; Murley, T.; Edgar, G.; Silverman, D. NRC regulation of DOE facilities. Nuclear News 40: 28-33; 1997.

Chamberlain, A.C. Interception and retention of radioactive aerosols by vegetation. Atmospheric Environment 4: 57-78: 1970.

Hamby, D.M. Land and water use characteristics in the vicinity of the Savannah River Site. Aiken, SC: Westinghouse Savannah River Company; WSRC-RP-91-17; 1991.

Hamby, D.M. Verification of the GASPAR dose assessment module used in MAXIGASP and POPGASP. Aiken, SC: Westinghouse Savannah River Company; WSRC-RP92-418; 1992.

Hamby, D.M.; Bauer, L.R. The vegetation-to-air concentration ratio in a specific activity atmospheric tritium model. Health Physics 66: 339-342; 1994.

Hermann, O.W.; Beas, C.F. III; Miller, C.W.; Begovich, C.L.; Sjoreen, A.L. PRIMUS: A computer code for the preparation of radionuclide ingrowth matrices from userspecified sources. Oak Ridge, TN: Oak Ridge National Laboratory; ORNL-5912; 1984. 
Internation Commission on Radiological Protection. Limits for intakes of radionuclides by workers, Publication 30. Pergamon Press: New York; 1978.

Kirchner, T.B.; Whicker, F.W. Validation of PATHWAY, a simulation model of the transport of radionuclides through agroecosystems. Ecological Modeling 22: 2144; 1984.

Koranda, J.J.; Martin, J.R. The movement of tritium in ecological systems. In: Moghissi, A.A.; Carter, M.W., eds. Tritium. Pheonix, AZ: Messenger Graphics; 1973.

Looney, B.B.; Grant, M.W.; King, C.M. Environmental information document: Estimation of geochemical parameters for assessing subsurface transport at the Savannah River Plant. Aiken, SC: E.I. du Pont de Nemours \& Co., Savannah River Laboratory; DPST-85-904; 1987.

Müller, H.; Pröhl, G. ECOSYS-87: a dynamic model for assessing radiological consequences of nuclear accidents. Health Physics 64: 232-252; 1993.

Murphy, C.E. Jr.; Wortham, G.R. An atmospheric tritium release database for model comparisons. Aiken, SC: Westinghouse Savannah River Company; WSRC-TR91-671, Rev 2; 1997.

Napier, B.A.; Peloquin, R.A.; Strenge, D.L.; Ramsdell, J.V. GENII - The Hanford environmental radiation dosimetry software system; Volume 1 - Conceptual Representation. Richland, WA: Pacific Northwest Laboratory; PNL-6584; 1988.

National Council on Radiation Protection and Measurements. Radiological assessment: Predicting the transport, bioaccumulation, and uptake by man of radionuclides released to the environment. Bethesda: NCRP Report No. 76; 1984.

$\mathrm{Ng}, \mathrm{Y}$.C. A review of transfer factors for assessing the dose from radionuclides in agricultural products. Nuclear Safety 23: 57-71; 1982.

Ng, Y.C.; Phillips, W.A.; Ricker, Y.E.; Tandy, R.K.; Thompson, S.E. Methodology for assessing dose commitment to individuals and to the population from ingestion of terrestrial foods contaminated by emissions from a nuclear fuel reprocessing plant at the Savannah River Plant. Livermore, CA: Lawrence Livermore Laboratory; UCID-17743; 1978.

Peterson Jr., H.T. Terrestrial and aquatic food chain pathways. In: Till, J.E.; Meyer, H.R., eds. Radiological assessment: A textbook on environmental dose analysis. Washington, DC: US Nuclear Regulatory Commission; NUREG/CR-3332; 1983.

Pillinger, M.M.; Huang, J.C. AXAIR: A computer code for SAR assessment of plumeexposure doses from potential process-accident releases to atmosphere. Aiken, SC: E.I. du Pont de Nemours, Savannah River Laboratory; DPST-85-304; 1986. 
Pinder III, J.E.; Ciravolo, T.G.; Bowling, J.W. The interrelationships among plant biomass, plant surface area and the interception of particulate deposition by grasses. Health Physics 55: 51-58: 1988.

Raskob, W. UFOTRI: Program for assessing the off-site consequences from accidental tritium releases. Kernforschungșzentrum Karlsruhe: KfK-4605; 1991.

Sanchez, D.A.; Allen, R.C.; Kyner, W.T. Differential equations: An introduction. Addison-Wesley Publishing Company: Reading, Mass., 1983.

Simmonds, J.R.; Linsley, G.S. Parameters for modeling the interception and retention of deposits from atmosphere by grain and leafy vegetables. Health Physics 43: 679 691: 1982.

Simpkins, A.A. AXAIRQ user's manual. Aiken, SC: Westinghouse Savannah River Company; WSRC-RP-95-709; 1995 .

Simpkins, A.A. Verification of AXAIRQ. Aiken, SC: Westinghouse Savannah River Company; WSRC-RP-95-708; 1995 b.

Simpkins, A.A.; Kurzeja, R.J. AXAIR and PUFF-PLUME Comparison (U). Aiken, SC: Westinghouse Savannah River Company; WSRC-RP-93-1322; 1993.

Sprung, J.L.; Rollstin, J.A.; Helton, J.C.; Jow, H-N. Evaluation of severe accident risks: Quantification of major input parameters; MACCS input, Vol 2. Albuquerque, NM: Sandia National Laboratories; SAND86-1309, NUREG/CR-4551; 1990.

Twining, S.; Strydom, J.; Rosson, R:; Kahn, B. Foodstuff monitoring at SRS. Atlanta, GA: Georgia ERDA, ERDA Project 94070; 1996.

U.S. Department of Energy. Internal dose conversion factors for calculation of dose to the public. Washington, DC: U.S. Government Printing Office: DOE/EH-0071: 1988.

U.S. Environmental Protection Agency. Manual of protection action guides and protective actions for nuclear incidents. Washington, DC: U.S. Government Printing Office: US EPA EPA-R-92-001: 1991.

U.S. Nuclear Regulatory Commission. Calculation of annual dose to man from routine releases of reactor effluents for the purpose of evaluating compliance with 10CFR Part 50, Appendix I. Washington, DC: U.S. Government Printing Office: US NRC Regulatory Guide 1.109: 1977.

U.S. Nuclear Regulatory Commission. Methods for estimating atmospheric transport and dispersion of gaseous effluents in routine releases from light-water-cooled reactors. Washington, DC: U.S. Government Printing Office: US NRC Regulatory Guide 1.111: 1977. 
U.S. Nuclear Regulatory Commission. Atmospheric dispersion models for potential accident consequence assessments at nuclear power plants. Washington, DC: U.S. Government Printing Office: US NRC Regulatory Guide 1.145: 1982.

U.S. Nuclear Regulatory Commission. Code of federal regulations. Washington, DC: U.S. Government Printing Office; 10CFR Part 72: 1995.

Whicker, F.W.; Kirchner, T.B. PATHWAY: a dynamic food-chain model to predict radionuclide ingestion after fallout deposition. Health Physics 52: 717-737; 1987.

Whicker, F.W.; Kirchner, T.B.; Breshears, D.D.; Otis, M.D. Estimation of radionuclide ingestion, the "PATHWAY" food-chain model. Health Physics: 645-657; 1990. 


\subsection{APPENDICES}

\subsection{List of equations and variables}

The equations below are provided as a simplification for programing. The equations follow in order of use, with a summary equation following.

\subsubsection{Vegetables}

$$
\begin{aligned}
& D E P=\chi * V_{d} * t_{d e p} \\
& \text { DEP amount deposited on surface }\left(\mathrm{Ci} / \mathrm{m}^{2}\right) \\
& \begin{array}{ll}
\chi & \text { relative air concentration }\left(\mathrm{Ci} / \mathrm{m}^{3}\right) ; \text { calculated in AXAMET95 } \\
V & \text { deposition velocity }(\mathrm{EPA} 1991)
\end{array} \\
& 0.01 \mathrm{~m} / \mathrm{s} \text { for iodines; } 0.001 \mathrm{~m} / \mathrm{s} \text { for particulates } \\
& t_{\text {dep }} \quad \text { deposition time (s); user-entered length of release } \\
& f_{v}=1-e^{-\alpha B} \text { and } f_{s}=1-f_{v}=e^{-\alpha B} \\
& \alpha \quad \text { foliar interception constant } \\
& 2.9 \mathrm{~m}^{2} / \mathrm{kg} \\
& \text { B standing crop biomass at time of deposition (dry } \mathrm{kg} / \mathrm{m}^{2} \text { ) } \\
& 0.45 \mathrm{~kg} / \mathrm{m}^{2} \text { pasture grass; } 0.19 \mathrm{~kg} / \mathrm{m}^{2} \text { leafy vegetables; } \\
& 0.11 \mathrm{~kg} / \mathrm{m}^{2} \text { fruit and other vegetables } \\
& C_{v}^{o}=D E P * f_{v} \quad \text { and } \quad C_{s}^{o}=D E P * f_{s} \\
& C_{v}^{o} \quad \text { initial vegetation contamination }\left(\mathrm{Ci} / \mathrm{m}^{2}\right) \\
& C_{s}^{o} \quad \text { initial surface soil contamination }\left(\mathrm{Ci} / \mathrm{m}^{2}\right) \\
& C_{v}^{h}=\frac{C_{v}^{o}}{B} \\
& C_{v}^{h} \quad \text { concentration at harvest }(\mathrm{Ci} / \mathrm{kg}) \\
& \text { B amount harvested (Hamby 1991) } \\
& 0.70 \mathrm{~kg} / \mathrm{m} 2 \text { (wet) for both leafy and other vegetables } \\
& C_{v}^{c}=C_{v}^{h} f_{p} e^{-\lambda_{r} t} \\
& C_{v}^{c} \quad \text { radionuclide concentration in vegetation at consumption }(\mathrm{Ci} / \mathrm{kg}) \\
& C_{v j}^{n} \quad \text { concentration of radionuclide in leafy or other vegetation at harvest }(\mathrm{Ci} / \mathrm{kg}) \\
& f_{p} \quad \text { fraction of activity remaining after preparation and processing } \\
& 0.1 \text { other vegetables and fruit; } 0.5 \text { leafy vegetables } \\
& \lambda_{r} \quad \text { radiological decay constant for each radionuclide }\left(\mathrm{d}^{-1}\right) \\
& t \quad \text { time held in storage (d) (Hamby 1991) } \\
& 1 \mathrm{~d} \text { maximum individual, leafy and other vegetables } \\
& 14 \mathrm{~d} \text { population, all vegetables } \\
& I_{v}=C_{v}^{c} * A * l \\
& I_{v} \quad \text { radionuclide quantity ingested due to vegetable consumption }(\mathrm{Ci} / \mathrm{yr}) \\
& \stackrel{v}{A} \text { annual vegetable intake (Hamby 1991); only } 5 \text { days of consumption } \\
& \text { Avg indiv: } 0.288 \mathrm{~kg} \text { leafy; } 2.233 \mathrm{~kg} \text { other vegetables and fruit }
\end{aligned}
$$


MEI: $0.589 \mathrm{~kg}$ leafy; $3.781 \mathrm{~kg}$ other vegetables and fruit

$f \quad$ fraction of consumed vegetables locally produced

$100 \%$ leafy vegetables; $76 \%$ other vegetables

Summary Equation: $I_{v}=A * l *\left\{\left(\frac{\chi * V_{d} * t_{\text {dep }} * f_{v}}{B}\right) * f_{p} * e^{-\lambda_{r} * t}\right\}$

$C_{v}^{o}=\frac{0.5 * \chi}{H}$

For Tritium (HTO)

$C_{v}^{o} \quad$ initial concentration of tritiated water in vegetables $(\mathrm{pCi} / \mathrm{mL})$

$\chi \quad$ relative air concentration of HTO in atmosphere $\left(\mathrm{pCi} / \mathrm{m}^{3}\right)$; AXAMET95

$\mathrm{H}$ absolute humidity $-11.4 \mathrm{~mL} / \mathrm{m}^{3}$ (Arnett 1996)

$C_{v}^{h}=C_{v}^{o} * e^{-\lambda_{p} t}$

$C_{v}^{h} \quad$ concentration of HTO in vegetation at time of harvest $(\mathrm{pCi} / \mathrm{mL})$

$\lambda_{p} \quad$ disappearance rate constant of HTO in vegetable water, $0.693 \mathrm{~d}^{-1}$

$\mathrm{t}$ time between cessation of exposure and harvest, $0.5 \mathrm{~d}$

$C_{v}^{h^{\prime}}=C_{v}^{h} * W$

$C_{v}^{h^{\prime}} \quad$ concentration of tritium in vegetation $(\mathrm{pCi} / \mathrm{g})$

$\mathrm{W}$ ratio of water mass to total plant mass ( $\mathrm{g}$ water / $\mathrm{g}$ total plant mass)

0.75 pasture grass (Hamby 1991); 0.73 leafy vegetables and 0.85 fruit and other vegetables (Whicker and Kirchner 1987)

Summary Equation: $I_{v}=A * l *\left\{\left(\frac{0.54 * \chi * e^{-\lambda_{p} * t}}{W}\right) * e^{-\lambda_{r} * t}\right\}$

\subsubsection{Meat and Milk}

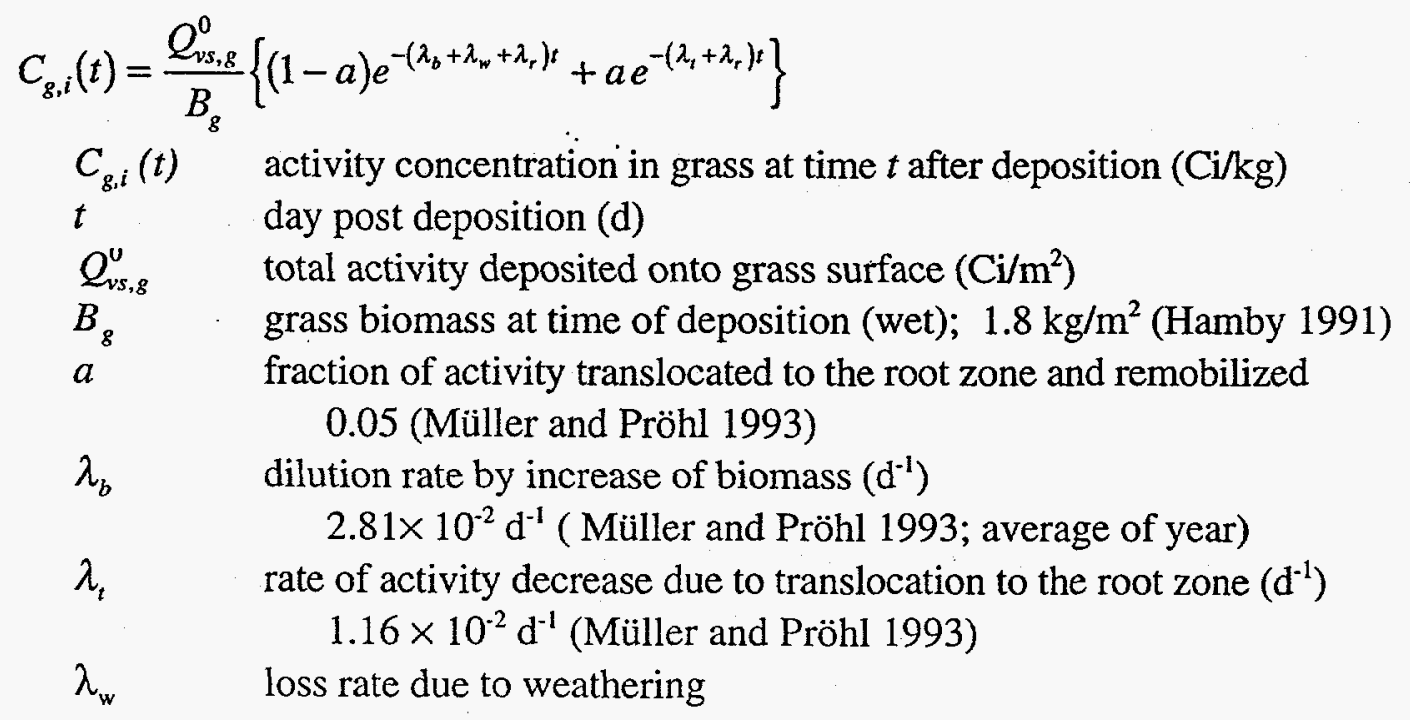


$4.95 \times 10^{-2} \mathrm{~d}^{-1}$ particulates (Whicker and Kirchner 1987, NCRP76)

$7.65 \times 10^{-2} \mathrm{~d}^{-1}$ iodines (Whicker and Kirchner 1987)

$$
\begin{aligned}
& Q_{v s, g}^{o}=D E P * f_{v} \text { and } Q_{s s}^{o}=D E P * f_{s} \\
& C_{s}(t)=\frac{Q_{s s}^{0}}{x_{l} p_{l}} e^{-\left(\lambda_{p}+\lambda_{r}\right) t}+\frac{Q_{s, g}^{0}}{B_{g}}\left(1-e^{-\left(\lambda_{w}+\lambda_{r}\right) t}\right)(1-a)
\end{aligned}
$$

$C_{s} \quad$ activity concentration in the surface soil at time $t$ after deposition $(\mathrm{Ci} / \mathrm{kg})$

$Q_{s s}^{0} \quad$ total activity deposited onto soil surface $\left(\mathrm{Ci} / \mathrm{m}^{2}\right)$

$x_{l} \quad$ depth of soil surface layer subject to ingestion; $1.0 \times 10^{-3} \mathrm{~m}$

$p_{l} \quad$ bulk density of surface soil; $1.6 \times 10^{3} \mathrm{~kg} / \mathrm{m}^{3}$ (Looney et al. 1987)

$\lambda_{p} \quad$ percolation rate constant; $1.98 \times 10^{-2} \mathrm{~d}^{-1}$ (Anspaugh et al. 1975)

$C_{m}(T)=T F_{m}\left\{\int_{0}^{T} A(t) \lambda_{b, m} * e^{-\left(\lambda_{b, m}+\lambda_{r}\right)(T-t)} d t\right\}$

$C_{m}(T) \quad$ activity concentration $(\mathrm{Ci} / \mathrm{kg})$ in animal product $m$ at time $\mathrm{T}$

$T F_{m} \quad$ transfer factor $(\mathrm{d} / \mathrm{kg})$ for animal product $m$

$\lambda_{b, m} \quad$ biological elimination rate for animal product $m\left(\mathrm{~d}^{-1}\right)$

$A(t) \quad$ activity intake rate of the animal on day $t(\mathrm{Ci} / \mathrm{d})$

beef cattle: consume 10 days of contaminated pasture

milk cow: consume 5 days contaminated pasture

$A(t)=C_{s}(t) I_{s}+C_{g} I_{g}$

$C(t) \quad$ activity concentration in soil (s) or pasture grass $(\mathrm{g})(\mathrm{Ci} / \mathrm{kg})$

$I(t) \quad$ daily intake rate for pasture grass $(\mathrm{g})$ or soil $(\mathrm{s})(\mathrm{kg} / \mathrm{d})$

$0.5 \mathrm{~kg} / \mathrm{d}$ soil; $27 \mathrm{~kg} / \mathrm{d}$ beef cattle pasture grass;

$29.12 \mathrm{~kg} / \mathrm{d}$ dairy cow pasture grass

$$
I_{m}=C_{m}(T) * A * l * e^{-\lambda_{r} t}
$$

$I_{m} \quad$ radionuclide quantity ingested due to animal product consumption (Ci/yr)

A annual animal product intake (Hamby 1991)

Avg indiv: $43 \mathrm{~kg} / \mathrm{yr}$ beef; $120 \mathrm{~L} / \mathrm{yr}$ milk

MEI: $81 \mathrm{~kg} / \mathrm{yr}$ beef; $230 \mathrm{~L} / \mathrm{yr}$ milk, only consume for 5 days

$l \quad$ fraction of consumed animal products locally produced

$100 \%$ MEI milk and beef; $2 \%$ population beef; $10 \%$ population milk

$\mathrm{t}$ transport time between milking/slaughter and consumption

$6 \mathrm{~d}$ beef population and MEI; $3 \mathrm{~d}$ milk population; $0 \mathrm{~d}$ milk MEI 


\subsection{Hand Calculations}

\subsubsection{Examination of First vs. Later Years Harvest Dose Contribution}

To ensure the elimination of following years harvests does not significantly reduce dose, the following calculations were performed.

Release from center of site: $1 \mathrm{Ci}$ each Cs-137, I-125. Calculate MEI and average individual dose for consumption of human food crops harvested after deposition.

\section{Cs-137 MEI:}

Worst-case sector is NNW with $\chi / \mathrm{Q}=5.126 \mathrm{E}-6 \mathrm{~s} / \mathrm{m}^{3}$. $\mathrm{DEP}=5.126 \mathrm{E}-6 \mathrm{~s} / \mathrm{m}^{3} * 1 \mathrm{Ci} * 0.001 \mathrm{~m} / \mathrm{s}=5.1 \mathrm{E}-9 \mathrm{Ci} / \mathrm{m}^{2}$ leafy $\mathrm{f}_{\mathrm{v}}=1-\mathrm{e}^{-(2.9 \mathrm{~m} 2 / \mathrm{kg} * 0.19 \mathrm{~kg} / \mathrm{m} 2)}=0.42 \quad$ other $\mathrm{f}_{\mathrm{v}}=1-\mathrm{e}^{-(2.9 \mathrm{~m} 2 / \mathrm{kg} * 0.11 \mathrm{~kg} / \mathrm{m} 2)}=0.27$

Leafy: $C^{\text {h }}{ }_{\mathrm{v}}=5.1 \mathrm{E}-9 \mathrm{Ci} / \mathrm{m}^{2} * 0.42 \div 0.7 \mathrm{~kg} / \mathrm{m}^{2}=3.1 \mathrm{E}-9 \mathrm{Ci} / \mathrm{kg}$ $\mathrm{C}_{\mathrm{v}}^{\mathrm{c}}=3.1 \mathrm{E}-9 \mathrm{Ci} / \mathrm{kg} * 0.5 * \mathrm{e}^{-(\ln 2 * 1 \mathrm{~d}+11012 \mathrm{~d})}=1.6 \mathrm{E}-9 \mathrm{Ci} / \mathrm{kg}$ $\mathrm{I}=1.6 \mathrm{E}-9 \mathrm{Ci} / \mathrm{kg} * 43 \mathrm{~kg} / \mathrm{yr} \div 365 \mathrm{~d} / \mathrm{yr} * 5 \mathrm{~d} * 100 \%=9.1 \mathrm{E}-10 \mathrm{Ci}$

Other vegetables and fruits: $\mathrm{C}_{\mathrm{v}}^{\mathrm{h}}=5.1 \mathrm{E}-9 \mathrm{Ci} / \mathrm{m}^{2} * 0.27 \div 0.7 \mathrm{~kg} / \mathrm{m}^{2}=2.0 \mathrm{E}-9 \mathrm{Ci} / \mathrm{kg}$

$\mathrm{C}_{\mathrm{v}}^{\mathrm{c}}=2.0 \mathrm{E}-9 \mathrm{Ci} / \mathrm{kg} * 0.1 * \mathrm{e}^{-(\ln 2 * 1 \mathrm{~d}+11012 \mathrm{~d})}=2.0 \mathrm{E}-10 \mathrm{Ci} / \mathrm{kg}$

$\mathrm{I}=2.0 \mathrm{E}-10 \mathrm{Ci} / \mathrm{kg} * 276 \mathrm{~kg} / \mathrm{yr} * 5 \mathrm{~d} \div 365 \mathrm{~d} / \mathrm{yr} * 76 \%=5.8 \mathrm{E}-10 \mathrm{Ci}$

Dose: $\mathrm{D}=(9.1 \mathrm{E}-10 \mathrm{Ci}+5.8 \mathrm{E}-10 \mathrm{Ci}) *(1 \mu \mathrm{Ci} / 1 \mathrm{E}-6 \mathrm{Ci}) *(5.0 \mathrm{E}-2 \mathrm{rem} / \mu \mathrm{Ci})=$

7.4E-5 rem

Cs-137 Average Individual Dose:

To represent the population dose, a one person "average individual" dose is calculated. For purposes of a simplistic estimate, this uses the worst sector $80 \mathrm{~km} \chi / \mathrm{Q}$.

Worst-case sector is $\mathrm{N}$ with $\chi / \mathrm{Q}=2.048 \mathrm{E}-6 \mathrm{~s} / \mathrm{m}^{3}$.

$\mathrm{DEP}=2.048 \mathrm{E}-6 \mathrm{~s} / \mathrm{m}^{2} * 1 \mathrm{Ci} * 0.001 \mathrm{~m} / \mathrm{s}=2.0 \mathrm{E}-9 \mathrm{Ci} / \mathrm{m}^{2}$

Leafy: $\mathrm{C}_{\mathrm{v}}^{\mathrm{h}}=2.0 \mathrm{E}-9 \mathrm{Ci} / \mathrm{m}^{2} * 0.42 \div 0.7 \mathrm{~kg} / \mathrm{m}^{2}=1.2 \mathrm{E}-9 \mathrm{Ci} / \mathrm{kg}$

$\mathrm{C}_{\mathrm{v}}^{\mathrm{c}}=1.2 \mathrm{E}-9 \mathrm{Ci} / \mathrm{kg} * 0.5 * \mathrm{e}^{-(\ln 2 * 14 \mathrm{~d}+11012 \mathrm{~d})}=6.2 \mathrm{E}-10 \mathrm{Ci} / \mathrm{kg}$

$\mathrm{I}=6.2 \mathrm{E}-10 \mathrm{Ci} / \mathrm{kg} * 21 \mathrm{~kg} / \mathrm{yr} * 1 \mathrm{yr} * 5 \%=6.5 \mathrm{E}-10 \mathrm{Ci}$

Other vegetables and fruits: $C_{\mathrm{v}}^{\mathrm{h}}=2.0 \mathrm{E}-9 \mathrm{Ci} / \mathrm{m}^{2} * 0.27 \div 0.7 \mathrm{~kg} / \mathrm{m}^{2}=8.0 \mathrm{E}-10 \mathrm{Ci} / \mathrm{kg}$

$\mathrm{C}_{\mathrm{v}}^{\mathrm{c}}=8.0 \mathrm{E}-10 \mathrm{Ci} / \mathrm{kg} * 0.1 * \mathrm{e}^{-(\ln 2 * 14 \mathrm{~d}+11012 \mathrm{~d})}=8.0 \mathrm{E}-11 \mathrm{Ci} / \mathrm{kg}$

$\mathrm{I}=8.0 \mathrm{E}-11 \mathrm{Ci} / \mathrm{kg} * 163 \mathrm{~kg} / \mathrm{yr} * 1 \mathrm{yr} * 5 \%=6.5 \mathrm{E}-10 \mathrm{Ci}$

Dose: $\mathrm{D}=(6.5 \mathrm{E}-10 \mathrm{Ci}+6.5 \mathrm{E}-10 \mathrm{Ci}) *(1 \mu \mathrm{Ci} / 1 \mathrm{E}-6 \mathrm{Ci}) *(5.0 \mathrm{E}-2 \mathrm{rem} / \mu \mathrm{Ci})=$

\subsection{E-5 rem}

\section{I-125 MEI:}

Worst-case sector is NNW with $\chi / \mathrm{Q}=5.126 \mathrm{E}-6 \mathrm{~s} / \mathrm{m}^{3}$. $\mathrm{DEP}=5.126 \mathrm{E}-6 \mathrm{~s} / \mathrm{m}^{3} * 1 \mathrm{Ci} * 0.01 \mathrm{~m} / \mathrm{s}=5.1 \mathrm{E}-8 \mathrm{Ci} / \mathrm{m}^{2}$ Leafy: $\mathrm{C}_{\mathrm{v}}^{\mathrm{h}}=5.1 \mathrm{E}-8 \mathrm{Ci} / \mathrm{m}^{2} * 0.42 \div 0.7 \mathrm{~kg} / \mathrm{m}^{2}=3.1 \mathrm{E}-8 \mathrm{Ci} / \mathrm{kg}$ 


$$
\begin{aligned}
& \mathrm{C}_{\mathrm{v}}^{\mathrm{c}}=3.1 \mathrm{E}-8 \mathrm{Ci} / \mathrm{kg} * 0.5 * \mathrm{e}^{-(\ln 2 * 1 \mathrm{~d}+59.9 \mathrm{~d})}=1.5 \mathrm{E}-8 \mathrm{Ci} / \mathrm{kg} \\
& \mathrm{I}=1.5 \mathrm{E}-8 \mathrm{Ci} / \mathrm{kg} * 43 \mathrm{~kg} / \mathrm{yr} * 5 \mathrm{~d} \div 365 \mathrm{~d} / \mathrm{yr} * 100 \%=9.0 \mathrm{E}-9 \mathrm{Ci}
\end{aligned}
$$

Other vegetables and fruits: $\mathrm{C}_{\mathrm{v}}^{\mathrm{h}}=5.1 \mathrm{E}-8 \mathrm{Ci} / \mathrm{m}^{2} * 0.27 \div 0.7 \mathrm{~kg} / \mathrm{m}^{2}=2.0 \mathrm{E}-8 \mathrm{Ci} / \mathrm{kg}$

$$
\mathrm{C}_{\mathrm{v}}^{\mathrm{c}}=2.0 \mathrm{E}-8 \mathrm{Ci} / \mathrm{kg} * 0.1 * \mathrm{e}^{-(\ln 2 * 1 \mathrm{~d}+59.9 \mathrm{~d})}=2.0 \mathrm{E}-9 \mathrm{Ci} / \mathrm{kg}
$$$$
\mathrm{I}=2.0 \mathrm{E}-9 \mathrm{Ci} / \mathrm{kg} * 276 \mathrm{~kg} / \mathrm{yr} * 5 \mathrm{~d} \div 365 \mathrm{~d} / \mathrm{yr} * 76 \%=5.7 \mathrm{E}-9 \mathrm{Ci}
$$

Dose: $\mathrm{D}=(9.0 \mathrm{E}-9 \mathrm{Ci}+5.7 \mathrm{E}-9 \mathrm{Ci}) *(1 \mu \mathrm{Ci} / 1 \mathrm{E}-6 \mathrm{Ci}) *(3.8 \mathrm{E}-2 \mathrm{rem} / \mu \mathrm{Ci})=$

\section{$5.6 \mathrm{E}-4$ rem}

I-125 Average Individual Dose:

Worst-case sector is $\mathrm{N}$ with $\chi / \mathrm{Q}=2.048 \mathrm{E}-6 \mathrm{~s} / \mathrm{m}^{3}$.

$\mathrm{DEP}=2.048 \mathrm{E}-6 \mathrm{~s} / \mathrm{m}^{3} * 1 \mathrm{Ci} * 0.01 \mathrm{~m} / \mathrm{s}=2.0 \mathrm{E}-8 \mathrm{Ci} / \mathrm{m}^{2}$

Leafy: $C^{\text {h }}{ }_{v}=2.0 \mathrm{E}-8 \mathrm{Ci} / \mathrm{m}^{2} * 0.42 \div 0.7 \mathrm{~kg} / \mathrm{m}^{2}=1.2 \mathrm{E}-8 \mathrm{Ci} / \mathrm{kg}$

$\mathrm{C}_{\mathrm{v}}^{\mathrm{c}}=1.2 \mathrm{E}-8 \mathrm{Ci} / \mathrm{kg} * 0.5 * \mathrm{e}^{-(\ln 2 * 14 \mathrm{~d}+59.9 \mathrm{~d})}=5.3 \mathrm{E}-9 \mathrm{Ci} / \mathrm{kg}$

$\mathrm{I}=5.3 \mathrm{E}-9 \mathrm{Ci} / \mathrm{kg} * 21 \mathrm{~kg} / \mathrm{yr} * 1 \mathrm{yr} * 5 \%=5.5 \mathrm{E}-9 \mathrm{Ci}$

Other vegetables and fruits: $C^{\mathrm{h}}{ }_{\mathrm{v}}=2.0 \mathrm{E}-8 \mathrm{Ci} / \mathrm{m}^{2} * 0.27 \div 0.7 \mathrm{~kg} / \mathrm{m}^{2}=8.0 \mathrm{E}-9 \mathrm{Ci} / \mathrm{kg}$

$\mathrm{C}_{\mathrm{v}}^{\mathrm{c}}=8.0 \mathrm{E}-9 \mathrm{Ci} / \mathrm{kg} * 0.1 * \mathrm{e}^{-(\ln 2 * 14 \mathrm{~d}+59.9 \mathrm{~d})}=6.8 \mathrm{E}-10 \mathrm{Ci} / \mathrm{kg}$

$\mathrm{I}=6.8 \mathrm{E}-10 \mathrm{Ci} / \mathrm{kg} * 163 \mathrm{~kg} / \mathrm{yr} * 1 \mathrm{yr} * 5 \%=5.5 \mathrm{E}-9 \mathrm{Ci}$

Dose: $\mathrm{D}=(5.5 \mathrm{E}-9 \mathrm{Ci}+5.5 \mathrm{E}-9 \mathrm{Ci}) *(1 \mu \mathrm{Ci} / 1 \mathrm{E}-6 \mathrm{Ci}) *(3.8 \mathrm{E}-2 \mathrm{rem} / \mu \mathrm{Ci})=$

\subsection{E-4 rem}

For the above accident, calculate the dose from consumption of human food crops during the second season. (crops contaminated due to root uptake and resuspension)

Sets of differential equations (Appendix 9.2.4) used to examine the transfer of radionuclides during the winter and during the following growing seasons were solved using the fourth order Runge-Kutta (Sanchez et al. 1983). These equations were used to calculate the internal and external vegetation contamination and the end of the second growing season. Since it is assumed that vegetables are consumed for only 5 days following an accident, AXINGST "holds" or stores vegetables for only 1 day. However, Hamby (1991) recommends a hold time of 60 days for other vegetables and fruit and 1 day for leafy vegetables. These values are used in the calculations for subsequent years harvests.

Cs-137 MEI:

\begin{tabular}{|l|l|l|l|}
\hline & Internal $\left(\mathrm{Ci} / \mathrm{m}^{2}\right)$ & External $\left(\mathrm{Ci} / \mathrm{m}^{2}\right)$ & Total $\left(\mathrm{Ci} / \mathrm{m}^{2}\right)$ \\
\hline Leafy Vegetables & $1.5 \mathrm{E}-13$ & $1.5 \mathrm{E}-13$ & $3.0 \mathrm{E}-13$ \\
Other Vegetables & $109 \mathrm{E}-13$ & $1.9 \mathrm{E}-13$ & $3.8 \mathrm{E}-13$ \\
\hline
\end{tabular}


Leafy: $C_{\mathrm{v}}^{\mathrm{h}}=3.0 \mathrm{E}-13 \mathrm{Ci} / \mathrm{m}^{2} \div 0.7 \mathrm{~kg} / \mathrm{m}^{2}=4.3 \mathrm{E}-13 \mathrm{Ci} / \mathrm{kg}$

$\mathrm{C}_{\mathrm{v}}^{\mathrm{c}}=4.3 \mathrm{E}-13 \mathrm{Ci} / \mathrm{kg} * 0.5 * \mathrm{e}^{-(\ln 2 * 1 \mathrm{~d}+11012 \mathrm{~d})}=2.1 \mathrm{E}-13 \mathrm{Ci} / \mathrm{kg}$

$\mathrm{I}=2.1 \mathrm{E}-13 \mathrm{Ci} / \mathrm{kg} * 43 \mathrm{~kg} / \mathrm{yr} * 1 \mathrm{yr} * 100 \%=9.2 \mathrm{E}-12 \mathrm{Ci}$

Other vegetables and fruits: $\mathrm{C}_{\mathrm{v}}^{\mathrm{h}}=3.8 \mathrm{E}-13 \mathrm{Ci} / \mathrm{m}^{2} \div 0.7 \mathrm{~kg} / \mathrm{m}^{2}=5.4 \mathrm{E}-13 \mathrm{Ci} / \mathrm{kg}$

$\mathrm{C}_{\mathrm{v}}^{\mathrm{c}}=5.4 \mathrm{E}-13 \mathrm{Ci} / \mathrm{kg} * 0.1 * \mathrm{e}^{-(\ln 2 * 60 \mathrm{~d}+11012 \mathrm{~d})}=5.4 \mathrm{E}-14 \mathrm{Ci} / \mathrm{kg}$

$\mathrm{I}=5.4 \mathrm{E}-14 \mathrm{Ci} / \mathrm{kg} * 276 \mathrm{~kg} / \mathrm{yr} * 1 \mathrm{yr} * 76 \%=1.1 \mathrm{E}-11 \mathrm{Ci}$

Dose: $\mathrm{D}=(9.2 \mathrm{E}-12 \mathrm{Ci}+1.1 \mathrm{E}-11 \mathrm{Ci}) *(1 \mu \mathrm{Ci} / 1 \mathrm{E}-6 \mathrm{Ci}) *(5.0 \mathrm{E}-2 \mathrm{rem} / \mu \mathrm{Ci})=$

$1.0 \mathrm{E}-6 \mathrm{rem}$

Cs-137 Average Individual Dose:

\begin{tabular}{|l|l|l|l|}
\hline & Internal $\left(\mathrm{Ci} / \mathrm{m}^{2}\right)$ & External $\left(\mathrm{Ci} / \mathrm{m}^{2}\right)$ & Total $\left(\mathrm{Ci} / \mathrm{m}^{2}\right)$ \\
\hline Leafy Vegetables & $6.1 \mathrm{E}-14$ & $6.1 \mathrm{E}-14$ & $1.2 \mathrm{E}-13$ \\
Other Vegetables & $7.7 \mathrm{E}-14$ & $7.7 \mathrm{E}-14$ & $1.5 \mathrm{E}-13$ \\
\hline
\end{tabular}

Leafy: $\mathrm{C}_{\mathrm{v}}^{\circ}=1.2 \mathrm{E}-13 \mathrm{Ci} / \mathrm{m}^{2} \div 0.7 \mathrm{~kg} / \mathrm{m}^{2}=1.7 \mathrm{E}-13 \mathrm{Ci} / \mathrm{kg}$

$\mathrm{C}_{\mathrm{v}}^{\mathrm{c}}=1.7 \mathrm{E}-13 \mathrm{Ci} / \mathrm{kg} * 0.5 * \mathrm{e}^{-(\ln 2 * 14 \mathrm{~d}+11012 \mathrm{~d})}=8.7 \mathrm{E}-14 \mathrm{Ci} / \mathrm{kg}$

$\mathrm{I}=8.7 \mathrm{E}-14 \mathrm{Ci} / \mathrm{kg} * 21 \mathrm{~kg} / \mathrm{yr} * 1 \mathrm{yr} * 5 \%=9.1 \mathrm{E}-14 \mathrm{Ci}$

Other vegetables and fruits: $\mathrm{C}_{\mathrm{v}}^{\mathrm{o}}=1.5 \mathrm{E}-13 \mathrm{Ci} / \mathrm{m}^{2} \div 0.7 \mathrm{~kg} / \mathrm{m}^{2}=2.2 \mathrm{E}-13 \mathrm{Ci} / \mathrm{kg}$

$\mathrm{C}_{\mathrm{v}}^{\mathrm{c}}=2.2 \mathrm{E}-13 \mathrm{Ci} / \mathrm{kg} * 0.1 * \mathrm{e}^{-(\ln 2 * 14 \mathrm{~d}+(11012 \mathrm{~d})}=2.2 \mathrm{E}-14 \mathrm{Ci} / \mathrm{kg}$

$\mathrm{I}=2.2 \mathrm{E}-14 \mathrm{Ci} / \mathrm{kg} * 163 \mathrm{~kg} / \mathrm{yr} * 1 \mathrm{yr} * 5 \%=1.8 \mathrm{E}-13 \mathrm{Ci}$

Dose: $\mathrm{D}=(9.1 \mathrm{E}-14 \mathrm{Ci}+1.8 \mathrm{E}-13 \mathrm{Ci}) *(1 \mu \mathrm{Ci} / 1 \mathrm{E}-6 \mathrm{Ci}) *(5.0 \mathrm{E}-2 \mathrm{rem} / \mu \mathrm{Ci})=$

\subsection{E-8 rem}

I-125 MEI:

\begin{tabular}{|l|l|l|l|}
\hline & Internal $\left(\mathrm{Ci} / \mathrm{m}^{2}\right)$ & External $\left(\mathrm{Ci} / \mathrm{m}^{2}\right)$ & Total $\left(\mathrm{Ci} / \mathrm{m}^{2}\right)$ \\
\hline Leafy Vegetables & $2.4 \mathrm{E}-14$ & $2.4 \mathrm{E}-14$ & $4.8 \mathrm{E}-14$ \\
Other Vegetables & $3.0 \mathrm{E}-14$ & $3.0 \mathrm{E}-14$ & $6.0 \mathrm{E}-14$ \\
\hline
\end{tabular}

Leafy: $\mathrm{C}_{\mathrm{v}}^{\mathrm{h}}=4.8 \mathrm{E}-14 \mathrm{Ci} / \mathrm{m}^{2} \div 0.7 \mathrm{~kg} / \mathrm{m}^{2}=6.8 \mathrm{E}-14 \mathrm{Ci} / \mathrm{kg}$

$\mathrm{C}_{\mathrm{v}}^{\mathrm{c}}=6.8 \mathrm{E}-14 \mathrm{Ci} / \mathrm{kg} * 0.5 * \mathrm{e}^{-(\ln 2 * 1 \mathrm{~d}+59.9 \mathrm{~d})}=3.4 \mathrm{E}-14 \mathrm{Ci} / \mathrm{kg}$

$\mathrm{I}=3.4 \mathrm{E}-14 \mathrm{Ci} / \mathrm{kg} * 43 \mathrm{~kg} / \mathrm{yr} * 1 \mathrm{yr} * 100 \%=1.4 \mathrm{E}-12 \mathrm{Ci}$

Other vegetables and fruits: $\mathrm{C}_{\mathrm{v}}^{\mathrm{h}}=6.0 \mathrm{E}-14 \mathrm{Ci} / \mathrm{m}^{2} \div 0.7 \mathrm{~kg} / \mathrm{m}^{2}=8.6 \mathrm{E}-14 \mathrm{Ci} / \mathrm{kg}$

$\mathrm{C}_{\mathrm{v}}^{\mathrm{c}}=8.6 \mathrm{E}-14 \mathrm{Ci} / \mathrm{kg} * 0.1 * \mathrm{e}^{-(\ln 2 * 60 \mathrm{~d}+11012 \mathrm{~d})}=4.3 \mathrm{E}-15 \mathrm{Ci} / \mathrm{kg}$

$\mathrm{I}=4.3 \mathrm{E}-15 \mathrm{Ci} / \mathrm{kg} * 276 \mathrm{~kg} / \mathrm{yr} * 1 \mathrm{yr} * 76 \%=9.0 \mathrm{E}-13 \mathrm{Ci}$

Dose: $\mathrm{D}=(1.4 \mathrm{E}-12 \mathrm{Ci}+9.0 \mathrm{E}-13 \mathrm{Ci}) *(1 \mu \mathrm{Ci} / 1 \mathrm{E}-6 \mathrm{Ci}) *(3.8 \mathrm{E}-2 \mathrm{rem} / \mu \mathrm{Ci})=$

\subsection{E-8 rem}


I-125 Average Individual Dose:

\begin{tabular}{|l|l|l|l|}
\hline & Internal $\left(\mathrm{Ci} / \mathrm{m}^{2}\right)$ & External $\left(\mathrm{Ci} / \mathrm{m}^{2}\right)$ & Total $\left(\mathrm{Ci} / \mathrm{m}^{2}\right)$ \\
\hline Leafy Vegetables & $9.5 \mathrm{E}-15$ & $9.5 \mathrm{E}-15$ & $1.9 \mathrm{E}-14$ \\
Other Vegetables & $1.2 \mathrm{E}-14$ & $1.2 \mathrm{E}-14$ & $2.4 \mathrm{E}-13$ \\
\hline
\end{tabular}

Leafy: $\mathrm{C}_{\mathrm{v}}^{\mathrm{h}}=1.9 \mathrm{E}-14 \mathrm{Ci} / \mathrm{m}^{2} \div 0.7 \mathrm{~kg} / \mathrm{m}^{2}=2.7 \mathrm{E}-14 \mathrm{Ci} / \mathrm{kg}$

$\mathrm{C}_{\mathrm{v}}^{\mathrm{c}}=2.7 \mathrm{E}-14 \mathrm{Ci} / \mathrm{kg} * 0.5 * \mathrm{e}^{-(\ln 2 * 14 \mathrm{~d}+59.9 \mathrm{~d})}=1.3 \mathrm{E}-14 \mathrm{Ci} / \mathrm{kg}$

$\mathrm{I}=1.3 \mathrm{E}-14 \mathrm{Ci} / \mathrm{kg} * 21 \mathrm{~kg} / \mathrm{yr} * 1 \mathrm{yr} * 5 \%=1.4 \mathrm{E}-14 \mathrm{Ci}$

Other vegetables and fruits: $\mathrm{C}_{\mathrm{v}}^{\mathrm{h}}=2.4 \mathrm{E}-13 \mathrm{Ci} / \mathrm{m}^{2} \div 0.7 \mathrm{~kg} / \mathrm{m}^{2}=3.4 \mathrm{E}-13 \mathrm{Ci} / \mathrm{kg}$

$\mathrm{C}_{\mathrm{v}}^{\mathrm{c}}=3.4 \mathrm{E}-13 \mathrm{Ci} / \mathrm{kg} * 0.1 * \mathrm{e}^{-(\ln 2 * 14 \mathrm{~d}+59.9 \mathrm{~d})}=3.4 \mathrm{E}-14 \mathrm{Ci} / \mathrm{kg}$

$\mathrm{I}=3.4 \mathrm{E}-14 \mathrm{Ci} / \mathrm{kg} * 163 \mathrm{~kg} / \mathrm{yr} * 1 \mathrm{yr} * 5 \%=2.8 \mathrm{E}-13 \mathrm{Ci}$

Dose: $\mathrm{D}=(1.4 \mathrm{E}-14 \mathrm{Ci}+2.8 \mathrm{E}-13 \mathrm{Ci}) *(1 \mu \mathrm{Ci} / 1 \mathrm{E}-6 \mathrm{Ci}) *(3.8 \mathrm{E}-2 \mathrm{rem} / \mu \mathrm{Ci})=$

\subsection{E-8 rem}

\subsubsection{Comparison of Ingestion Dose vs. Inhalation Dose}

To determine the increase in reported dose calculated by AXAIRQ after the addition of AXINGST, the following calculations were performed.

Release: 2 Ci I-135 and 4 Ci Cs-137 over $8760 \mathrm{hr}$; WSW worst sector $\chi / \mathrm{Q}=9.572 \mathrm{E}-5 \mathrm{~s} / \mathrm{m}^{3}$. Cs-137:

$\mathrm{DEP}=9.572 \mathrm{E}-5 \mathrm{~s} / \mathrm{m}^{3} * 4 \mathrm{Ci} * 0.001 \cdot \mathrm{m} / \mathrm{s}=3.8 \mathrm{E}-7 \mathrm{Ci} / \mathrm{m}^{2}$

leafy $\mathrm{f}_{\mathrm{v}}=0.42$; other $\mathrm{f}_{\mathrm{v}}=0.27$; pasture $\mathrm{f}_{\mathrm{v}}=1-\mathrm{e}^{-(2.9 \mathrm{~m} 2 \mathrm{k \textrm {kg }} * 0.45 \mathrm{~kg} / \mathrm{m} 2)}=0.73$

Leafy: $\mathrm{C}_{\mathrm{v}}^{\mathrm{b}}=3.8 \mathrm{E}-7 \mathrm{Ci} / \mathrm{m}^{2} * 0.42 \div 0.7 \mathrm{~kg} / \mathrm{m}^{2}=2.3 \mathrm{E}-7 \mathrm{Ci} / \mathrm{kg}$

$\mathrm{C}_{\mathrm{v}}^{\mathrm{c}}=2.3 \mathrm{E}-7 \mathrm{Ci} / \mathrm{kg} * 0.5 * \mathrm{e}^{-(\ln 2 * 1 \mathrm{~d}+11012 \mathrm{~d})}=1.1 \mathrm{E}-7 \mathrm{Ci} / \mathrm{kg}$

$\mathrm{I}=1.1 \mathrm{E}-7 \mathrm{Ci} / \mathrm{kg} * 43 \mathrm{~kg} / \mathrm{yr} \div 365 \mathrm{~d} / \mathrm{yr} * 5 \mathrm{~d} * 100 \%=6.8 \mathrm{E}-8 \mathrm{Ci}$

Other vegetables and fruits: $\mathrm{C}_{\mathrm{v}}^{\mathrm{h}}=3.8 \mathrm{E}-7 \mathrm{Ci} / \mathrm{m}^{2} * 0.27 \div 0.7 \mathrm{~kg} / \mathrm{m}^{2}=1.5 \mathrm{E}-7 \mathrm{Ci} / \mathrm{kg}$

$\mathrm{C}_{\mathrm{v}}^{\mathrm{c}}=1.5 \mathrm{E}-7 \mathrm{Ci} / \mathrm{kg} * 0.1 * \mathrm{e}^{-(\ln 2 * 1 \mathrm{~d}+11012 \mathrm{~d})}=1.5 \mathrm{E}-8 \mathrm{Ci} / \mathrm{kg}$

$\mathrm{I}=1.5 \mathrm{E}-8 \mathrm{Ci} / \mathrm{kg} * 276 \mathrm{~kg} / \mathrm{yr} * 5 \mathrm{~d} \div 365 \mathrm{~d} / \mathrm{yr} * 76 \%=4.3 \mathrm{E}-8 \mathrm{Ci}$

Pasture grass: Equations solved in EXCEL to have daily values; values not reported here

$$
\begin{aligned}
\mathrm{C}_{\mathrm{g}}(\mathrm{t})= & \left(3.8288 \mathrm{E}-7 \mathrm{Ci} / \mathrm{m}^{2} * 0.73 \div 1.8 \mathrm{~kg} / \mathrm{m}^{2}\right) *\{(0.95 * \\
& \left.\left.\mathrm{e}^{-(2.81 \mathrm{E}-2 \mathrm{~d}-1+4.95 \mathrm{E}-2 \mathrm{~d}-1+6.2944 \mathrm{e}-5 \mathrm{~d}-1) \mathrm{t}}\right)+\left(0.05 * \mathrm{e}^{-(1.16 \mathrm{E}-2 \mathrm{~d}-1+6.2944 \mathrm{E}-5 \mathrm{~d}-1) \mathrm{t}}\right)\right\} \\
\mathrm{C}_{\mathrm{s}}(\mathrm{t})= & \left\{\left(3.8288 \mathrm{E}-7 \mathrm{Ci} / \mathrm{m}^{2} * 0.27 \div 1 \mathrm{E}-3 \mathrm{~m} \div 1.6 \mathrm{E} 3 \mathrm{~kg} / \mathrm{m}^{3}\right) * \mathrm{e}^{-(1.98 \mathrm{E}-2 \mathrm{~d}-1+6.2944 \mathrm{E}-5 \mathrm{~d}-1) \mathrm{t}}\right\} \\
+ & \left\{\left(3.8288 \mathrm{E}-7 \mathrm{Ci} / \mathrm{m}^{2} * 0.73 \div 1.8 \mathrm{~kg} / \mathrm{m}^{2}\right) *\left(1-\mathrm{e}^{-(4.95 \mathrm{E}-2 \mathrm{~d}-1) \mathrm{t}}\right) * \mathrm{e}^{-(6.2944 \mathrm{E}-5 \mathrm{~d}-1) \mathrm{t} * 0.95\}}\right.
\end{aligned}
$$

Meat: All equations are solved in EXCEL to have daily values; values are not reported here

$$
\begin{aligned}
& \mathrm{A}(\mathrm{t})=\mathrm{C}_{\mathrm{g}}(\mathrm{t}) * 27 \mathrm{~kg} / \mathrm{d}+\mathrm{C}_{\mathrm{s}}(\mathrm{t}) * 0.5 \mathrm{k} / \mathrm{d} \\
& \mathrm{C}_{\text {meat }}=(4.0 \mathrm{E}-3 \mathrm{~d} / \mathrm{kg})\left\{\text { INT. } 0-10 \mathrm{~d} \mathrm{~A}(\mathrm{t}) * 1.4 \mathrm{E}-2 \mathrm{~d}^{-1} * \mathrm{e}^{-(1.4 \mathrm{E}-2 \mathrm{~d}-1+6.2944 \mathrm{E}-5 \mathrm{~d}-1)(\mathrm{T}-\mathrm{t})} \mathrm{dt}\right\}
\end{aligned}
$$




$$
\begin{aligned}
& =4.0 \mathrm{E}-3 \mathrm{~d} / \mathrm{kg} * 3.84 \mathrm{E}-8 \mathrm{Ci} / \mathrm{d}=1.54 \mathrm{E}-10 \mathrm{Ci} / \mathrm{kg} \\
\mathrm{I} & =1.54 \mathrm{E}-10 \mathrm{Ci} / \mathrm{kg} * 81 \mathrm{~kg} / \mathrm{yr} * 100 \% * \mathrm{e}-(\ln 2 * 6 \mathrm{~d} * 11012 \mathrm{~d})=1.3 \mathrm{E}-8 \mathrm{Ci}
\end{aligned}
$$

Milk: All equations are solved in EXCEL to have daily values; values are not reported here

$$
\begin{aligned}
& \mathrm{A}(\mathrm{t})=\mathrm{C}_{\mathrm{g}}(\mathrm{t}) \mathrm{Ci} / \mathrm{kg} * 29.12 \mathrm{~kg} / \mathrm{d}+\mathrm{C}_{\mathrm{s}}(\mathrm{t}) \mathrm{Ci} / \mathrm{kg} * 0.5 \mathrm{k} / \mathrm{d} \\
& \mathrm{C}_{\text {meat }}=(1.2 \mathrm{E}-2 \mathrm{~d} / \mathrm{L})\left\{\mathrm{INT} 0-5 \mathrm{~d} \mathrm{~A}(\mathrm{t}) * 3.8 \mathrm{E}-1 \mathrm{~d}^{-1} * \mathrm{e}^{-(3.8 \mathrm{E}-1 \mathrm{~d}-\mathrm{l}+6.2944 \mathrm{E}-\mathrm{s} \mathrm{d}-1)(\mathrm{T}-\mathrm{t})} \mathrm{dt}\right\} \\
& \quad=1.2 \mathrm{E}-2 \mathrm{~d} / \mathrm{L} * 3.04 \mathrm{E}-7 \mathrm{Ci} / \mathrm{d}=3.7 \mathrm{E}-9 \mathrm{Ci} / \mathrm{L} \\
& \mathrm{I}=3.7 \mathrm{E}-9 \mathrm{Ci} / \mathrm{L} * 230 \mathrm{~L} / \mathrm{yr} * 5 \mathrm{~d} \div 365 \mathrm{~d} / \mathrm{yr} * 100 \% * \mathrm{e}^{-(\ln 2 * 6 \mathrm{~d}+11012 \mathrm{~d})}=1.2 \mathrm{E}-8 \mathrm{Ci}
\end{aligned}
$$

Dose $=(6.8 \mathrm{E}-8 \mathrm{Ci}+4.3 \mathrm{E}-8 \mathrm{Ci}+1.3 \mathrm{E}-8 \mathrm{Ci}+1.2 \mathrm{E}-8 \mathrm{Ci}) *(1 \mu \mathrm{Ci} / 1 \mathrm{E}-6 \mathrm{Ci}) *$

$$
(5.0 \mathrm{E}-2 \mathrm{rem} / \mu \mathrm{Ci})=6.8 \mathrm{mrem}
$$

compared to the test case results of (from AXAIRQ):

Inhalation Dose: $3.4 \mathrm{E}-2$ mrem

thus for this case, AXINGST increases the dose by a factor of $\sim 200$

$$
\text { I-135: }
$$

$\mathrm{DEP}=9.572 \mathrm{E}-5 \mathrm{~s} / \mathrm{m}^{3} * 2 \mathrm{Ci} * 0.01 \mathrm{~m} / \mathrm{s}=1.9 \mathrm{E}-6 \mathrm{Ci} / \mathrm{m}^{2}$

Leafy: $\mathrm{C}_{\mathrm{v}}^{\mathrm{o}}=1.9 \mathrm{E}-6 \mathrm{Ci} / \mathrm{m}^{2} * 0.42 \div 0.7 \mathrm{~kg} / \mathrm{m}^{2}=1.2 \mathrm{E}-6 \mathrm{Ci} / \mathrm{kg}$

$$
\mathrm{C}_{\mathrm{v}}^{\mathrm{c}}=1.2 \mathrm{E}-6 \mathrm{Ci} / \mathrm{kg} * 0.5 * \mathrm{e}^{-(\ln 2 * 1 \mathrm{~d}+.274375 \mathrm{~d})}=4.6 \mathrm{E}-8 \mathrm{Ci} / \mathrm{kg}
$$$$
\mathrm{I}=4.6 \mathrm{E}-8 \mathrm{Ci} / \mathrm{kg} * 43 \mathrm{~kg} / \mathrm{yr} \div 365 \mathrm{~d} / \mathrm{yr} * 5 \mathrm{~d} * 100 \%=2.7 \mathrm{E}-8 \mathrm{Ci}
$$

Other vegetables and fruits: $\mathrm{C}_{\mathrm{y}}^{\mathrm{o}}=1.9144 \mathrm{E}-6 \mathrm{Ci} / \mathrm{m}^{2} * 0.27 \div 0.7 \mathrm{~kg} / \mathrm{m}^{2}=7.4 \mathrm{E}-7 \mathrm{Ci} / \mathrm{kg}$

$$
\begin{aligned}
& \mathrm{C}_{\mathrm{v}}^{\mathrm{c}}=7.48 \mathrm{E}-7 \mathrm{Ci} / \mathrm{kg} * 0.1 * \mathrm{e}^{-(\ln 2 * 1 \mathrm{~d} * .274375 \mathrm{~d})}=5.9 \mathrm{E}-9 \mathrm{Ci} / \mathrm{kg} \\
& \mathrm{I}=5.9 \mathrm{E}-9 \mathrm{Ci} / \mathrm{kg} * 276 \mathrm{~kg} / \mathrm{yr} * 5 \mathrm{~d} \div 365 \mathrm{~d} / \mathrm{yr} * 76 \%=1.7 \mathrm{E}-8 \mathrm{Ci}
\end{aligned}
$$

Pasture grass: Equations solved in EXCEL to have daily values; values not reported here

$$
\begin{aligned}
& \mathrm{C}_{\mathrm{g}}(\mathrm{t})=\left(1.9 \mathrm{E}-6 \mathrm{Ci} / \mathrm{m}^{2} * 0.73 \div 1.8 \mathrm{~kg} / \mathrm{m}^{2}\right) *\left\{\left(0.95 * \mathrm{e}^{-(2.81 \mathrm{E}-2 \mathrm{~d}-1+4.95 \mathrm{E}-2 \mathrm{~d}-1+}\right.\right. \\
& \left.2.7437 \mathrm{EE}-1 \mathrm{~d}-1) \mathrm{t})+\left(0.05 * \mathrm{e}^{-(1.16 \mathrm{E}-2 \mathrm{~d}-1+2.74375 \mathrm{E}-1 \mathrm{~d}-1) \mathrm{t}}\right)\right\} \\
& \mathrm{C}_{\mathrm{s}}(\mathrm{t})=\left\{\left(1.9144 \mathrm{E}-6 \mathrm{Ci} / \mathrm{m}^{2} * 0.27 \div 1 \mathrm{E}-3 \mathrm{~m} \div 1.6 \mathrm{E} 3 \mathrm{~kg} / \mathrm{m}^{3}\right) * \mathrm{e}^{-(1.98 \mathrm{E}-2 \mathrm{~d}-1+2.74375 \mathrm{E}-1 \mathrm{~d}-1) \mathrm{t}}\right\} \\
& \quad+\left\{\left(1.9144 \mathrm{E}-6 \mathrm{Ci} / \mathrm{m} 2 * 0.73 \div 1.8 \mathrm{~kg} / \mathrm{m}^{2}\right) *\left(1-\mathrm{e}^{-(4.95 \mathrm{E}-2 \mathrm{~d}-11+2.74375 \mathrm{E}-1 \mathrm{~d}-1) \mathrm{t}}\right) * 0.95\right\}
\end{aligned}
$$

Meat and Milk: Due to the short half life of I-135 (6.585 hours), the dose due to consumption of meat and milk, which occurs days after the incident (16 and 8, respectively) will be essentially zero.

Dose $=(2.7 \mathrm{E}-8 \mathrm{Ci}+1.7 \mathrm{E}-8 \mathrm{Ci}) *(1 \mu \mathrm{Ci} / 1 \mathrm{E}-6 \mathrm{Ci}) *(2.0 \mathrm{E}-3 \mathrm{rem} / \mu \mathrm{Ci})=\mathbf{8 . 8 E}-2 \mathrm{mrem}$ compared to the test case results of (from AXAIRQ):

Inhalation Dose: $5.7 \mathrm{E}-4$ mrem

Plume Shine: $3.6 \mathrm{E}-4 \mathrm{mrem}$

thus for this case, AXINGST increases the dose by a factor of $\sim 95$, however, for shortlived radionuclides such as I-135, the ingestion dose can essentially be eliminated by including a hold factor 


\subsubsection{Indication of conservativeness}

These calculations are used to determine how conservative the $99.5 \% \chi / \mathrm{Q}$ MEI calculations are compared to a more realistic scenario using the $95 \% \chi / \mathrm{Q}$.

\section{Cs-137:}

$\mathrm{DEP}=3.305 \mathrm{E}-6 \mathrm{~s} / \mathrm{m}^{3} * 4 \mathrm{Ci} * 0.001 \mathrm{~m} / \mathrm{s}=1.322 \mathrm{E}-8 \mathrm{Ci} / \mathrm{m}^{2}$

Leafy: $\mathrm{I}=1.1 \mathrm{E}-9 \mathrm{Ci}$

Other vegetables and fruits: $\mathrm{I}=8.7 \mathrm{E}-10 . \mathrm{Ci}$

Meat: $\mathrm{I}=2.3 \mathrm{E}-10 \mathrm{Ci}$

Milk: $\mathrm{I}=2.1 \mathrm{E}-10 \mathrm{Ci}$

Dose $=(1.1 \mathrm{E}-9 \mathrm{Ci}+8.7 \mathrm{E}-10 \mathrm{Ci}+2.3 \mathrm{E}-10 \mathrm{Ci}+2.1 \mathrm{E}-10 \mathrm{Ci}) *(1 \mu \mathrm{Ci} / 1 \mathrm{E}-6 \mathrm{Ci}) *$

$$
(5.0 \mathrm{E}-2 \mathrm{rem} / \mu \mathrm{Ci})=\mathbf{0 . 1 2} \mathrm{mrem}
$$

Compared to the MEI of $6.8 \mathrm{mrem}$.

Using the less conservative $95 \% \chi / \mathrm{Q}$ and consumption values for an average individual, with the individual living on the site boundary, the calculated dose if 50 times less than the MEI (99.5\% $\chi / \mathrm{Q}$, maximum consumption values).

\subsubsection{Equations for Winter and Following Seasons}

The following equations are used to calculate the radionuclide concentration in vegetation and soil during the following growing seasons. These sets of differential equations are solved using the Fourth Order Runge-Kutta method.

$$
\begin{aligned}
& \text {. Winter } \\
& \frac{d Q_{s s}}{d t}=-\left(\lambda_{p}+\lambda_{r}\right) Q_{s s}^{o} \\
& Q_{s s} \quad \text { inventroy in soil surface }\left(\mathrm{Ci} / \mathrm{m}^{2}\right) \\
& \lambda_{\mathrm{p}} \quad \text { percolation rate constant }\left(\mathrm{d}^{-1}\right) \\
& \lambda_{\mathrm{r}} \quad \text { radiological decay rate constant }\left(\mathrm{d}^{-1}\right) \\
& \frac{d Q_{r s}}{d t}=\lambda_{p} Q_{s s}-\lambda_{r} Q_{r s} \\
& Q_{r s} \quad \text { inventory in root soil }\left(\mathrm{Ci} / \mathrm{m}^{2}\right) \\
& \text { Growing Season } \\
& \frac{d Q_{s s}}{d t}=-\left(\lambda_{p}+\lambda_{r, r s}+\lambda_{r}\right) Q_{s s}+\lambda_{w} Q_{v s} \\
& \lambda_{\mathrm{r}, \mathrm{rs}} \text { resuspension and rainsplash rate constant; } 2.56 \mathrm{E}-3 \mathrm{~d}^{-1} \\
& \lambda_{\mathrm{w}} \quad \text { weathering rate constant; } 4.95 \mathrm{E}-2 \mathrm{~d}^{-1} \\
& Q_{v s} \quad \text { inventory in vegetation surface }\left(\mathrm{Ci} / \mathrm{m}^{2}\right)
\end{aligned}
$$


$\frac{d Q_{r s}}{d t}=\lambda_{p} Q_{s s}-\lambda_{r} Q_{r s}-Q_{r s} C R\left(K_{f} \frac{B M A X * e^{\ln \left(\frac{B M A X-B I}{B I}\right)-K_{g} t}}{\left(1+e^{\ln \left(\frac{B M A X-B I}{B I}\right)-K_{g} t}\right)^{2}}\right) \div x_{l} p_{l}$

CR concentration ratio for root uptake (Baes et al. 1984)

BMAX maximum edible crop biomass ( $\mathrm{dry}, \mathrm{kg} / \mathrm{m}^{2}$ )

BI initial or winter biomass (Abbott and Rood 1993; Whicker and Kirchner 87) $0.015 \mathrm{~kg} / \mathrm{m}^{2}$ crops and grain; $0.07 \mathrm{~kg} / \mathrm{m}^{2}$ pasture grass; $0.08 \mathrm{~kg} / \mathrm{m}^{2}$ hay

$\mathrm{K}_{\mathrm{g}} \quad$ growth rate constant (Whicker and Kirchner 1987)

$0.12 \mathrm{~d}^{-1}$ crops and pasture; $0.27 \mathrm{~d}^{-1}$ hay

$x_{l} \quad$ depth of soil surface layer subject to ingestion; $1.0 \times 10^{-3} \mathrm{~m}$

$p_{l} \quad$ bulk density of surface soil; $1.6 \times 10^{3} \mathrm{~kg} / \mathrm{m}^{3}$ (Looney et al. 1987)

$\frac{d Q_{v s}}{d t}=\lambda_{r, r s} Q_{s s}-\left(\lambda_{w}+\lambda_{r}\right) Q_{v s}$
$\frac{d Q_{v i}}{d t}=R_{u p} Q_{r s}-\lambda_{r} Q_{v i}$

$Q_{v i} \quad$ inventory in vegetation surfaces $\left(\mathrm{Ci} / \mathrm{m}^{2}\right)$

$\mathrm{R}_{\mathrm{up}}$ root uptake, bracketed part of $Q_{r s}$ (Abbott and Rood 1993)

\subsubsection{Examination of Tritium Concentrations - AXINGST versus Measured}

99.5\% Dose : For a release near the center of site, AXAIRQ calculates the worst-sector MEI $\chi / \mathrm{Q}=5.126 \mathrm{E}-6$. This is in the NNW sector. For the following calculations, this release location will be used. All measured vegetation tritium concentrations come from Murphy and Wortham (1997).

Accident: 27 March 1981

Dis from Release to Perimeter: $17.4 \mathrm{~km}$ Max Veg Conc at Perimeter: $270 \mathrm{pCi} / \mathrm{mL}$ $\mathrm{C}_{\mathrm{v}}^{\mathrm{o}}=\left(0.5 * 5.126 \mathrm{E}-6 \mathrm{~s} / \mathrm{m}^{3} * 33,000 \mathrm{Ci} \div 2.5 \mathrm{hr} \div 3600 \mathrm{~s}\right) \div 11.4 \mathrm{~mL} / \mathrm{m}^{3}=8.24 \mathrm{E}-7 \mathrm{Ci} / \mathrm{mL}$ $\left.\mathrm{C}_{\mathrm{v}}^{\mathrm{h}}=8.24 \mathrm{E}-7 \mathrm{Ci} / \mathrm{mL} * \mathrm{e}^{-(\ln 2 * 0.5 \mathrm{~d}+1 \mathrm{~d}}\right)=5.83 \mathrm{E} 5 \mathrm{pCi} / \mathrm{mL}$

Conservativeness: $5.83 \mathrm{E} 5 \mathrm{pCi} / \mathrm{mL} \div 270 \mathrm{pCi} / \mathrm{mL}=-2160 \times$ higher

Accident: 27 March 1985

Dis from Release to Perimeter: $16.6 \mathrm{~km} \quad$ Max Veg Conc at Perimeter $970 \mathrm{pCi} / \mathrm{mL}$ $\mathrm{C}_{\mathrm{v}}^{\mathrm{o}}=\left(0.5 *\left(5.126 \mathrm{E}-6 \mathrm{~s} / \mathrm{m}^{3} * 1.5 \mathrm{Ci} / \mathrm{s}\right)\right) \div 11.4 \mathrm{~mL} / \mathrm{m}^{3}=3.37 \mathrm{E}-7 \mathrm{Ci} / \mathrm{mL}$

$\left.\mathrm{C}_{\mathrm{v}}^{\mathrm{h}}=3.37 \mathrm{E}-7 \mathrm{Ci} / \mathrm{mL} * \mathrm{e}^{-(\ln 2 * 0.5 \mathrm{~d}+1 \mathrm{~d}}\right)=2.38 \mathrm{E} 5 \mathrm{pCi} / \mathrm{mL}$

Conservativeness: $2.38 \mathrm{E} 5 \mathrm{pCi} / \mathrm{mL} \div 970 \mathrm{pCi} / \mathrm{mL}=\simeq 240 \times$ higher

Accident: 2 September 1984

Dis from Release to Perimeter: $10.3 \mathrm{~km}$ Max Veg Conc at Perimeter: $2500 \mathrm{pCi} / \mathrm{mL}$ $\mathrm{C}_{\mathrm{v}}^{\mathrm{o}}=\left(0.5 * 5.126 \mathrm{E}-6 \mathrm{~s} / \mathrm{m}^{3} * 43,800 \mathrm{Ci} \div 5 \mathrm{hr} \div 3600 \mathrm{~s} / \mathrm{hr}\right) \div 11.4 \mathrm{~mL} / \mathrm{m}^{3}=5.47 \mathrm{E}-7 \mathrm{Ci} / \mathrm{mL}$ $\left.\mathrm{C}_{\mathrm{v}}^{\mathrm{h}}=5.47 \mathrm{E}-7 \mathrm{Ci} / \mathrm{mL}^{*} \mathrm{e}^{-(\ln 2 * 0.5 \mathrm{~d}+1 \mathrm{~d}}\right)=3.87 \mathrm{E} 5 \mathrm{pCi} / \mathrm{mL}$ 
Conservativeness: $3.87 \mathrm{E} 5 \mathrm{pCi} / \mathrm{mL} \div 2500 \mathrm{pCi} / \mathrm{mL}=\sim 150 \times$ higher

Accident: 31 January 1985

Dis from Release to Perimeter: $14.9 \mathrm{~km} \quad$ Max Veg Conc at Perimeter: $450 \mathrm{pCi} / \mathrm{mL}$ $\mathrm{C}_{\mathrm{v}}^{\mathrm{o}}=\left(0.5 * 5.126 \mathrm{E}-6 \mathrm{~s} / \mathrm{m}^{3} * 9285 \mathrm{Ci} \div 3 \mathrm{hr} \div 3600 \mathrm{~s} / \mathrm{hr}\right) \div 11.4 \mathrm{~mL} / \mathrm{m}^{3}=1.93 \mathrm{E}-7 \mathrm{Ci} / \mathrm{mL}$ $\left.\mathrm{C}^{\mathrm{b}}{ }_{\mathrm{v}}=1.93 \mathrm{E}-7 \mathrm{Ci} / \mathrm{mL} * \mathrm{e}^{-(\ln 2 * 0.5 \mathrm{~d}+1 \mathrm{~d}}\right)=1.37 \mathrm{E} 5 \mathrm{pCi} / \mathrm{mL}$

Conservativeness: $1.37 \mathrm{E} 5 \mathrm{pCi} / \mathrm{mL} \div 450 \mathrm{pCi} / \mathrm{mL}=\simeq 300 \times$ higher

Accident: 23 March 1984

Dis from Release to Perimeter: $16.6 \mathrm{~km}$ Max Veg Conc at Perimeter: $500 \mathrm{pCi} / \mathrm{mL}$ $\mathrm{C}_{\mathrm{v}}^{\circ}=\left(0.5 * 5.126 \mathrm{E}-6 \mathrm{~s} / \mathrm{m}^{3} * 7500 \mathrm{Ci} \div 2.333 \mathrm{hr} \div 3600 \mathrm{~s} / \mathrm{hr}\right) \div 11.4 \mathrm{~mL} / \mathrm{m}^{3}=2.01 \mathrm{E}-7 \mathrm{Ci} / \mathrm{mL}$ $\left.\mathrm{C}^{\mathrm{h}}{ }_{\mathrm{v}}=2.01 \mathrm{E}-7 \mathrm{Ci} / \mathrm{mL} * \mathrm{e}^{-(\ln 2 * 0.5 \mathrm{~d}+1 \mathrm{~d}}\right)=1.42 \mathrm{E} 5 \mathrm{pCi} / \mathrm{mL}$

Conservativeness: $1.42 \mathrm{E} 5 \mathrm{pCi} / \mathrm{mL} \div 500 \mathrm{pCi} / \mathrm{mL}=\sim 280 \times$ higher

Actual Calculations: The diffusion coefficient equations found in Simpkins (1995b) were used to hand calculate the "actual" (instead of 99.5\%) tritium concentration in vegetation. Meteorological conditions for each accident were found in Murphy and Wortham (1997). Accident: 27 March 81

Calculated: $6414 \mathrm{pCi} / \mathrm{mL}$; Measured: $270 \mathrm{pCi} / \mathrm{mL}$

Over prediction: $24 \mathrm{x}$ increase

Accident: 23 March 84

Calculated: $2.338 \mathrm{E} 4 \mathrm{pCi} / \mathrm{mL} ; \quad$ Measured: $500 \mathrm{pCi} / \mathrm{mL}$

Over prediction: $47 \mathrm{x}$ increase

Accident: 31 January 85

Calculated: $1.947 \mathrm{E} 4 \mathrm{pCi} / \mathrm{mL}$; Measured: $450 \mathrm{pCi} / \mathrm{mL}$

Over prediction: $43 \mathrm{x}$ increase 
9.3 50-year Committed Dose Equivalent Factors for Ingestion, rem/ $\mu \mathrm{Ci}$ (USDOE 1988)

\begin{tabular}{|c|c|c|c|c|c|c|c|}
\hline Nuclide & $\mathrm{DF}$ & Nuclide & $\mathrm{DF}$ & Nuclide & DF & Nuclide & DF \\
\hline $\mathrm{H}-3$ & $6.3 \mathrm{E}-5$ & $\mathrm{Fe}-55$ & $5.8 \mathrm{E}-4$ & $\mathrm{Br}-80 \mathrm{M}$ & $2.3 \mathrm{E}-4$ & Mo-93 & $1.3 \mathrm{E}-3$ \\
\hline $\mathrm{Be}-7$ & $1.1 \mathrm{E}-4$ & $\mathrm{Fe}-59$ & $6.6 \mathrm{E}-3$ & $\mathrm{Br}-82$ & $1.7 \mathrm{E}-3$ & Mo-99 & $4.4 \mathrm{E}-3$ \\
\hline $\mathrm{Be}-10$ & $4.2 \mathrm{E}-3$ & $\mathrm{Co}-55$ & $4.1 \mathrm{E}-3$ & $\mathrm{Rb}-81$ & $1.3 \mathrm{E}-4$ & Mo-101 & $9.2 \mathrm{E}-5$ \\
\hline C-14 & $2.1 \mathrm{E}-3$ & $\mathrm{Co}-56$ & $1.2 \mathrm{E}-2$ & $\mathrm{Rb}-83$ & $7.7 \mathrm{E}-3$ & Tc-94 & $5.8 \mathrm{E}-4$ \\
\hline $\mathrm{Na}-22$ & $1.2 \mathrm{E}-2$ & $\mathrm{Co}-57$ & $1.1 \mathrm{E}-3$ & $\mathrm{Rb}-84$ & $1.2 \mathrm{E}-2$ & Тc-97M & $1.1 \mathrm{E}-3$ \\
\hline $\mathrm{Na}-24$ & $1.4 \mathrm{E}-3$ & $\mathrm{Co}-58 \mathrm{M}$ & $8.8 \mathrm{E}-5$ & $\mathrm{Rb}-86$ & $9.4 \mathrm{E}-3$ & Tc-97 & $1.5 \mathrm{E}-4$ \\
\hline $\mathrm{Mg}-28$ & $7.5 \mathrm{E}-3$ & Co-58 & $3.5 \mathrm{E}-3$ & $\mathrm{Rb}-87$ & $4.8 \mathrm{E}-3$ & Tc-98 & $4.8 \mathrm{E}-3$ \\
\hline Al-26 & $1.3 \mathrm{E}-2$ & $\mathrm{Co}-60$ & $2.6 \mathrm{E}-2$ & $\mathrm{Sr}-85$ & $1.9 \mathrm{E} 3$ & Tc-99M & $6.0 \mathrm{E}-5$ \\
\hline Si-32 & $1.7 \mathrm{E}-3$ & $\mathrm{Ni}-56$ & $3.5 \mathrm{E}-3$ & $\mathrm{Sr}-87 \mathrm{M}$ & $1.2 \mathrm{E}-4$ & Tc-99 & $1.3 \mathrm{E}-3$ \\
\hline $\mathrm{P}-32$ & 7.7E-3. & $\mathrm{Ni}-57$ & $3.3 \mathrm{E}-3$ & $\mathrm{Sr}-89$ & $8.7 \mathrm{E}-3$ & Ru-97 & $6.4 \mathrm{E}-4$ \\
\hline P-33 & $8.8 \mathrm{E}-4$ & $\mathrm{Ni}-59$ & $2.0 \mathrm{E}-4$ & $\mathrm{Sr}-90$ & $1.3 \mathrm{E}-3$ & $\mathrm{Ru}-103$ & $2.7 \mathrm{E}-3$ \\
\hline S-35 & $6.5 \mathrm{E}-4$ & $\mathrm{Ni}-63$ & $5.4 \mathrm{E}-4$ & $\operatorname{Sr}-91$ & $3.0 \mathrm{E}-3$ & Ru-105 & $1.0 \mathrm{E}-3$ \\
\hline $\mathrm{Cl}-36$ & $3.0 \mathrm{E}-3$ & $\mathrm{Cu}-61$ & 4.1E-4 & $\mathrm{Sr}-92$ & $1.6 \mathrm{E}-3$ & Ru-106 & $2.1 \mathrm{E}-2$ \\
\hline $\mathrm{K}-40$ & $1.9 \mathrm{E}-2$ & $\mathrm{Cu}-64$ & $4.3 \mathrm{E}-4$ & $\mathrm{Y}-86$ & $4.1 \mathrm{E}-3$ & $\mathrm{Rh}-105$ & $1.4 \mathrm{E}-3$ \\
\hline $\mathrm{K}-42$ & $1.1 \mathrm{E}-3$ & $\mathrm{Cu}-67$ & $1: 1 \mathrm{E}-3$ & $Y-87$ & $2.2 \mathrm{E}-3$ & Pd-103 & $6.9 \mathrm{E}-4$ \\
\hline $\mathrm{K}-43$ & $7.8 \mathrm{E}-4$ & $\mathrm{Zn}-62$ & $3.4 \mathrm{E}-3$ & $\mathrm{Y}-88$ & $5.2 \mathrm{E}-3$ & Pd-107 & $1.4 \mathrm{E}-4$ \\
\hline $\mathrm{Ca}-41$ & $1.2 \mathrm{E}-3$ & $\mathrm{Zn}-65$ & $1.4 \mathrm{E}-2$ & Y-90M & $6.6 \mathrm{E}-4$ & Pd-109 & $2.1 \mathrm{E}-3$ \\
\hline $\mathrm{Ca}-45$ & $3.0 \mathrm{E}-3$ & $\mathrm{Zn}-69 \mathrm{M}$ & $1.2 \mathrm{E}-3$ & $Y-90$ & $1.0 \mathrm{E}-2$ & Ag-106M & $6.1 \mathrm{E}-3$ \\
\hline $\mathrm{Ca}-47$ & $6.2 \mathrm{E}-3$ & $\mathrm{Ga}-66$ & $4.7 \mathrm{E}-3$ & $Y-91$ & $8.9 \mathrm{E}-3$ & $\mathrm{Ag}-108 \mathrm{M}$ & $7.5 \mathrm{E}-3$ \\
\hline Sc-44 & $1.4 \mathrm{E}-3$ & $\mathrm{Ga}-67$ & $7.2 \mathrm{E}-4$ & $Y-92$ & $1.9 \mathrm{E}-3$ & $\mathrm{Ag}-110 \mathrm{M}$ & $1.1 \mathrm{E}-2$ \\
\hline Sc-46 & $5.6 \mathrm{E}-3$ & $\mathrm{Ga}-72$ & $4.4 \mathrm{E}-3$ & $Y-93$ & $4.5 \mathrm{E}-3$ & Ag-111 & $4.5 \mathrm{E}-3$ \\
\hline Sc-47 & $1.9 \mathrm{E}-3$ & Ge-68 & $1.1 \mathrm{E}-3$ & $\mathrm{Zr}-86$ & $3.5 \mathrm{E}-3$ & Cd-109 & $1.2 \mathrm{E}-2$ \\
\hline $\mathrm{Sc}-48$ & $6.4 \mathrm{E}-3$ & $\mathrm{Ge}-71$ & $9.6 \mathrm{E}-6$ & $\mathrm{Zr}-88$ & $1.3 \mathrm{E}-3$ & Cd-113M & $1.5 \mathrm{E}-1$ \\
\hline Ti-44 & $1.9 \mathrm{E}-2$ & Ge-77 & $5.6 \mathrm{E}-4$ & $\mathrm{Zr}-89$ & $3.1 \mathrm{E}-3$ & $\mathrm{Cd}-113$ & $1.6 \mathrm{E}-1$ \\
\hline Ti-45 & $5.7 \mathrm{E}-4$ & As-72 & $5.6 \mathrm{E}-3$ & $Z r-93$ & $1.6 \mathrm{E}-3$ & $\mathrm{Cd}-115 \mathrm{M}$ & $1.5 \mathrm{E}-2$ \\
\hline$V-48$ & $7.5 \mathrm{E}-3$ & As-73 & $6.1 \mathrm{E}-4$ & $\mathrm{Zr}-95$ & $3.4 \mathrm{E}-3$ & Cd-115 & $4.7 \mathrm{E}-3$ \\
\hline$V-49$ & $5.4 \mathrm{E}-5$ & As-74 & $3.3 \mathrm{E}-3$ & $\mathrm{Zr}-97$ & $8.0 \mathrm{E}-3$ & $\mathrm{Cd}-117 \mathrm{M}$ & $1.1 \mathrm{E}-3$ \\
\hline $\mathrm{Cr}-48$ & $8.6 \mathrm{E}-4$ & As-76 & $4.8 \mathrm{E}-3$ & $\mathrm{Nb}-90$ & $4.9 \mathrm{E}-3$ & In-111 & $1.2 \mathrm{E}-3$ \\
\hline $\mathrm{Cr}-51$ & $1.3 \mathrm{E}-4$ & As-77 & $1.1 \mathrm{E}-3$ & $\mathrm{Nb}-93 \mathrm{M}$ & $5.3 \mathrm{E}-4$ & In-114M & $1.5 \mathrm{E}-2$ \\
\hline $\mathrm{Mn}-52$ & $6.9 \mathrm{E}-3$ & Se-73 & $1: 5 \mathrm{E}-3$ & $\mathrm{Nb}-94$ & $5.1 \mathrm{E}-3$ & In-115M & $3.4 \mathrm{E}-4$ \\
\hline $\mathrm{Mn}-53$ & $9.9 \mathrm{E}-5$ & Se-75 & $8.8 \mathrm{E}-3$ & $\mathrm{Nb}-95 \mathrm{M}$ & $2.0 \mathrm{E}-3$ & In-115 & $1.4 \mathrm{E}-4$ \\
\hline $\mathrm{Mn}-54$ & $2.7 \mathrm{E}-3$ & Se-79 & $8.3 \mathrm{E}-3$ & Nb-95 & $2.2 \mathrm{E}-3$ & Sn-113 & $2.7 \mathrm{E}-3$ \\
\hline $\mathrm{Fe}-52$ & $5.4 \mathrm{E}-3$ & $\mathrm{Br}-77$ & $3.1 \mathrm{E}-4$ & $\mathrm{Nb}-96$ & $4.4 \mathrm{E}-3$ & $\mathrm{Sn}-117 \mathrm{M}$ & $2.6 \mathrm{E}-3$ \\
\hline
\end{tabular}




\begin{tabular}{|c|c|c|c|c|c|c|c|}
\hline Nuclide & DF & Nuclide & DF & Nuclide & DF & Nuclide & DF \\
\hline Sn-119M & $1.2 \mathrm{E}-3$ & Cs-135 & $7.1 \mathrm{E}-3$ & Gd-153 & $1.1 \mathrm{E}-3$ & Ir -192 & $5.3 \mathrm{E}-3$ \\
\hline Sn-123 & $7.7 \mathrm{E}-3$ & Cs-136 & 1.1E-2 & Gd-159 & $1.9 \mathrm{E}-3$ & Ir-194M & $8.1 \mathrm{E}-3$ \\
\hline Sn-125 & $1.1 \mathrm{E}-2$ & Cs- 137 & $5.0 \mathrm{E}-2$ & Tb-157 & $1.0 \mathrm{E}-4$ & Ir-194 & $5.1 \mathrm{E}-3$ \\
\hline Sn-126 & $1.7 \mathrm{E}-2$ & Ba-131 & $1.6 \mathrm{E}-6$ & Tb-160 & $6.4 \mathrm{E}-3$ & Pt-191 & $1.3 \mathrm{E}-3$ \\
\hline Sb-117 & $7.4 \mathrm{E}-5$ & $\mathrm{Ba}-133 \mathrm{M}$ & $2.0 \mathrm{E}-3$ & Dy-157 & $2.7 \mathrm{E}-4$ & Pt-193M & $1.7 \mathrm{E}-3$ \\
\hline Sb-122 & $6.3 \mathrm{E}-3$ & $\mathrm{Ba}-133$ & $3.2 \mathrm{E}-3$ & Dy-166 & $6.2 \mathrm{E}-3$ & Pt-193 & $1.1 \mathrm{E}-4$ \\
\hline $\mathrm{Sb}-124$ & $9.3 \mathrm{E}-3$ & $\mathrm{Ba}-135 \mathrm{M}$ & $1.6 \mathrm{E}-3$ & Ho-166M & $7.8 \mathrm{E}-3$ & Pt-195M & $2.2 \mathrm{E}-3$ \\
\hline $\mathrm{Sb}-125$ & $2.6 \mathrm{E}-3$ & Ba-140 & $8.4 \mathrm{E}-3$ & Ho-166 & $5.5 \mathrm{E}-3$ & Pt-197 & $1.5 \mathrm{E}-3$ \\
\hline $\mathrm{Sb}-126$ & $9.6 \mathrm{E}-3$ & La-140 & 7.7E-3 & Er-169 & $1.4 \mathrm{E}-3$ & $\mathrm{Au}-194$ & $2.0 \mathrm{E}-3$ \\
\hline Sb-127 & $6.6 \mathrm{E}-3$ & La-141 & - $1.4 \mathrm{E}-3$ & Er-171 & $1.4 \mathrm{E}-3$ & $A u-195$ & $1.1 \mathrm{E}-3$ \\
\hline Sb-129 & $1.7 \mathrm{e}-3$ & $\mathrm{Ce}-137$ & $9.8 \mathrm{E}-5$ & $\operatorname{Tm}-170$ & $5.0 \mathrm{E}-3$ & $\mathrm{Au}-198$ & $2.3 \mathrm{E}-3$ \\
\hline $\mathrm{Te}-121 \mathrm{M}$ & $6.7 \mathrm{E}-3$ & Ce-139 & $1.1 \mathrm{E}-3$ & $\mathrm{Tm}-171$ & $3.9 \mathrm{E}-4$ & Au-199 & $1.8 \mathrm{E}-3$ \\
\hline Te-121 & $1.5 \mathrm{E}-3$ & Ce-141 & $2.6 \mathrm{E}-3$ & Yb-169 & $2.8 \mathrm{E}-3$ & $\mathrm{Hg}-193 \mathrm{M}$ & $1.6 \mathrm{E}-3$ \\
\hline $\mathrm{Te}-123 \mathrm{M}$ & $5.1 \mathrm{E}-3$ & Ce-143 & $4.2 \mathrm{E}-3$ & Yb-175 & $1.6 \mathrm{E}-3$ & $\mathrm{Hg}-193$ & $3.3 \mathrm{E}-4$ \\
\hline $\mathrm{Te}-123$ & $4.1 \mathrm{E}-3$ & Ce-144 & $2.0 \mathrm{E}-1$ & $\mathrm{Lu}-177 \mathrm{M}$ & $6.8 \mathrm{E}-3$ & $\mathrm{Hg}-194$ & $6.0 \mathrm{E}-3$ \\
\hline $\mathrm{Te}-125 \mathrm{M}$ & $3.4 \mathrm{E}-3$ & $\operatorname{Pr}-142$ & $5.1 \mathrm{E}-3$ & Lu-177 & $2.0 \mathrm{E}-3$ & $\mathrm{Hg}-195 \mathrm{M}$ & $2.2 \mathrm{E}-3$ \\
\hline $\mathrm{Te}-127 \mathrm{M}$ & $7.9 \mathrm{E}-3$ & $\operatorname{Pr}-143$ & $4.5 \mathrm{E}-3$ & Hf-181 & $4.3 \mathrm{E}-3$ & $\mathrm{Hg}-195$ & $3.8 \mathrm{E}-4$ \\
\hline Te-127 & $6.9 \mathrm{E}-4$ & Nd-147 & $3.9 e-3$ & Ta-182 & $6.0 \mathrm{E}-3$ & $\mathrm{Hg}-197 \mathrm{M}$ & $1.7 \mathrm{E}-3$ \\
\hline $\mathrm{Te}-129 \mathrm{M}$ & $9.9 \mathrm{E}-3$ & $\mathrm{Pm}-143$ & $9.5 \mathrm{E}-4$ & W-181 & $3.1 \mathrm{E}-4$ & $\mathrm{Hg}-197$ & $9.1 \mathrm{E}-4$ \\
\hline $\mathrm{Te}-131 \mathrm{M}$ & $1.5 \mathrm{E}-2$ & Pm-144 & $3.9 \mathrm{E}-3$ & W-185 & $1.9 \mathrm{E}-3$ & $\mathrm{Hg}-203$ & $2.1 \mathrm{E}-3$ \\
\hline Te-132 & $7.4 \mathrm{E}-3$ & $\mathrm{Pm}-145$ & $4.6 \mathrm{E}-4$ & W-187 & $2.6 \mathrm{E}-3$ & TI-200 & $6.7 \mathrm{E}-4$ \\
\hline I- 123 & $4.9 \mathrm{E}-4$ & Pm-146 & $3.2 \mathrm{E}-3$ & W-188 & $9.0 \mathrm{E}-3$ & Tl-201 & $2.9 \mathrm{E}-4$ \\
\hline I- 124 & $3.1 \mathrm{E}-2$ & Pm-147 & $9.5 \mathrm{E}-4$ & Re-182 & $3.4 \mathrm{E}-3$ & Tl-202 & $1.5 \mathrm{E}-3$ \\
\hline $\mathrm{I}-125$ & $3.8 \mathrm{E}-2$ & $\mathrm{Pm}-148 \mathrm{M}$ & 7.0E-3 & $\operatorname{Re}-184 \mathrm{M}$ & $2.4 \mathrm{E}-3$ & Tl-204 & $3.2 \mathrm{E}-3$ \\
\hline I- 126 & $7.1 \mathrm{E}-2$ & Pm-148 & $9.5 \mathrm{E}-3$ & $\operatorname{Re}-184$ & $2.2 \mathrm{E}-3$ & $\mathrm{~Pb}-203$ & $9.6 \mathrm{E}-4$ \\
\hline I-129 & $2.8 \mathrm{E}-1$ & Pm-149 & $3.6 \mathrm{E}-3$ & $\operatorname{Re}-186 \mathrm{M}$ & $3.3 \mathrm{E}-3$ & $\mathrm{~Pb}-205$ & $1.5 \mathrm{E}-3$ \\
\hline I -130 & $4.3 \mathrm{E}-3$ & Pm-151 & $2.8 \mathrm{E}-3$ & Re-186 & $2.6 \mathrm{E}-3$ & $\mathrm{~Pb}-209$ & $2.1 \mathrm{E}-4$ \\
\hline $\mathrm{I}-131$ & $5.3 \mathrm{E}-2$ & Sm-147 & $1.8 \mathrm{E}-1$ & $\operatorname{Re}-187$ & $8.3 E-6$ & $\mathrm{~Pb}-210$ & $5.4 \mathrm{E}+0$ \\
\hline I-133 & $1.0 \mathrm{E}-2$ & Sm-151 & $3.4 \mathrm{E}-4$ & Re-188 & $2.8 \mathrm{E}-3$ & $\mathrm{~Pb}-212$ & $4.1 \mathrm{E}-2$ \\
\hline I-135 & $2.0 \mathrm{E}-3$ & Sm-153 & $2.6 \mathrm{E}-3$ & Os- 185 & $2.1 \mathrm{E}-3$ & $\mathrm{Bi}-206$ & $8.0 \mathrm{E}-3$ \\
\hline Cs-129 & $2.2 \mathrm{E}-4$ & Eu-152 & $6.0 \mathrm{E}-3$ & Os-191M & $3.6 \mathrm{E}-4$ & $\mathrm{Bi}-207$ & $4.9 \mathrm{E}-3$ \\
\hline Cs-131 & $2.4 \mathrm{E}-4$ & Eu-154 & $9.1 \mathrm{E}-3$ & Os-191 & $2.0 \mathrm{E}-3$ & $\mathrm{Bi}-210$ & $5.9 \mathrm{E}-3$ \\
\hline Cs-132 & $1.9 \mathrm{E}-3$ & Eu-155 & $1.3 E-3$ & Os-193 & $3.1 \mathrm{E}-3$ & Po-210 & $1.6 \mathrm{E}+0$ \\
\hline Cs-134M & $4.2 \mathrm{E}-5$ & Eu-156 & 8.7E-3 & Ir-190M1 & $3.0 \mathrm{E}-5$ & At-211 & $4.1 \mathrm{E}-2$ \\
\hline
\end{tabular}




\begin{tabular}{ll|ll|ll|ll} 
Cs-134 & $7.4 \mathrm{E}-2$ & Gd-152 & $1.5 \mathrm{E}-1$ & Ir-190 & $4.9 \mathrm{E}-3$ & Ra-223 & $5.5 \mathrm{E}-1$ \\
Nuclide & DF & Nuclide & DF & Nuclide & DF & Nuclide & DF \\
\hline Ra-224 & $3.3 \mathrm{E}-1$ & $\mathrm{U}-230$ & $8.4 \mathrm{E}-1$ & Pu-238 & $3.8 \mathrm{E}+0$ & Cm-246 & $4.5 \mathrm{E}+0$ \\
Ra-225 & $3.1 \mathrm{E}-1$ & $\mathrm{U}-231$ & $1.1 \mathrm{E}-3$ & Pu-239 & $4.3 \mathrm{E}+0$ & Cm-247 & $4.1 \mathrm{E}+0$ \\
Ra-226 & $1.1 \mathrm{E}+0$ & $\mathrm{U}-232$ & $1.3 \mathrm{E}+0$ & Pu-240 & $4.3 \mathrm{E}+0$ & Cm-248 & $1.6 \mathrm{E}+1$ \\
Ra-228 & $1.2 \mathrm{E}+0$ & $\mathrm{U}-233$ & $2.7 \mathrm{E}-1$ & Pu-241 & $8.6 \mathrm{E}-2$ & Bk-249 & $6.0 \mathrm{E}-3$ \\
Ac-225 & $9.5 \mathrm{E}-2$ & $\mathrm{U}-234$ & $2.6 \mathrm{E}-1$ & Pu-242 & $4.1 \mathrm{E}+0$ & Bk-250 & $5.0 \mathrm{E}-4$ \\
Ac-227 & $1.4 \mathrm{E}+1$ & $\mathrm{U}-235$ & $2.5 \mathrm{E}-1$ & Pu-243 & $3.3 \mathrm{E}-4$ & Cf-248 & $2.8 \mathrm{E}-1$ \\
Ac-228 & $2.1 \mathrm{E}-3$ & $\mathrm{U}-236$ & $2.5 \mathrm{E}-1$ & Pu-244 & $4.0 \mathrm{E}+0$ & Cf-249 & $4.6 \mathrm{E}+0$ \\
Th-227 & $3.6 \mathrm{E}-2$ & $\mathrm{U}-237$ & $2.7 \mathrm{E}-3$ & Pu-245 & $2.4 \mathrm{E}-3$ & Cf-250 & $1.9 \mathrm{E}+0$ \\
Th-228 & $3.8 \mathrm{E}-1$ & $\mathrm{U}-238$ & $2.1 \mathrm{E}-1$ & Am-241 & $4.5 \mathrm{E}+0$ & Cf-251 & $4.6 \mathrm{E}+0$ \\
Th-229 & $3.5 \mathrm{E}+0$ & $\mathrm{U}-240$ & $4.1 \mathrm{E}-3$ & Am-242M & $4.2 \mathrm{E}+0$ & Cf-252 & $9.4 \mathrm{e}-1$ \\
Th-230 & $5.3 \mathrm{E}-1$ & Np-235 & $2.1 \mathrm{E}-4$ & Am-242 & $1.2 \mathrm{E}-3$ & Cf-253 & $9.2 \mathrm{E}-3$ \\
Th-231 & $1.3 \mathrm{E}-3$ & Np-236 & $7.9 \mathrm{E}-1$ & Am-243 & $4.5 \mathrm{E}+0$ & Cf-254 & $2.5 \mathrm{E}+0$ \\
Th-232 & $2.8 \mathrm{E}+0$ & Np-237 & $3.9 \mathrm{E}+0$ & Am-244 & $2.0 \mathrm{E}-3$ & Es-253 & $2.4 \mathrm{E}-2$ \\
Th-234 & $1.3 \mathrm{E}-2$ & Np-238 & $3.4 \mathrm{E}-3$ & Cm-242 & $1.1 \mathrm{E}-1$ & Es-254M & $1.5 \mathrm{E}-2$ \\
Pa-230 & $5.6 \mathrm{E}-3$ & Np-239 & $2.9 \mathrm{E}-3$ & $\mathrm{Cm}-243$ & $2.9 \mathrm{E}+0$ & Es-254 & $1.5 \mathrm{E}-1$ \\
Pa-231 & $1.1 \mathrm{E}+1$ & Pu-236 & $1.3 \mathrm{E}+0$ & $\mathrm{Cm}-244$ & $2.3 \mathrm{E}+0$ & Fm-254 & $1.6 \mathrm{E}-3$ \\
Pa-233 & $3.3 \mathrm{E}-3$ & Pu-237 & $1.0 \mathrm{E}-3$ & $\mathrm{Cm}-245$ & $4.5 \mathrm{E}+0$ & Fm-255 & $9.7 \mathrm{E}-3$ \\
Pa-234 & $2.1 \mathrm{E}-3$ & & & & & &
\end{tabular}

